\title{
Urban transformations: a history of design ideas
}

\author{
Julienne Hanson* \\ Reader in Architectural and Urban Morphology, The Bartlett School of Graduate Studies, (Torrington Place Site), \\ University College London, Gower Street, London WC1E 6BT, United Kingdom
}

“One superordinate question facing planners today is integration versus segregation"

This paper explores some configurational ideas that were first put together during the late 1970s, whilst 'space syntax' was still in gestation. They are part of a larger project to use space syntax analysis to retrieve a structured history of design ideas. Through the study of samples of real cases, the ability of space syntax to extract common 'genotypical' themes or 'design paradigms' from the built record will be used to show the shift in design paradigms over time. The ultimate goal will be to link these paradigm shifts into an account of changing social ideas.

The case study that will be presented in detail will examine the morphological changes that have taken place in the design of housing in a small Inner London neighbourhood, Somers Town, over a timespan of about a hundred years. In essence, the change is from 'streets', which seem rather similar to one another, to housing 'estates', which seem very different from one another. Yet although the various housing schemes that have been studied in detail look very heterogeneous, it is possible to detect a consistent line of development in their spatial layouts that is so strong and generic as to be genotypical. It will be argued that the origins of this genotype can be traced back to assumptions about social class, gender and ethnicity that took many years to develop and which have now been obscured by more recent debates.

Architecture has moved on and now, in the UK at least, we try design things that are very different from the estate layouts of Somers Town. The paper will try to explain 'how' and 'why', by unfolding the story that lies behind the design ideas and by bringing it up to date. The argument will be consolidated in two ways; by providing a more complete and quantitative syntactic analysis of the 1970s examples, and by showing how the changes in the way we think about housing in the 1990s have had an impact on contemporary housing in Somers Town, and in what has become the paradigm for the latest generation of design ideas, Hulme in Manchester. Finally, it will be argued that it is essential for architects and urban designers to understand how social ideas about inequalities in power and control get built into our frameworks and assumptions, and why, in the final analysis, architecture cannot be divorced from politics.

The answer to Robert Sommer's question "one superordinate question facing planners today is integration versus segregation" used to be thoroughgoing and uncompromising 'segregation'; now it is 'integration'. Today, permeability, integration and constitutedness are like 'motherhood and apple pie'. As design principles, it is assumed that they can 'do no wrong'. This ought to be a good thing for 'space syntax' since it was syntax that first drew attention to the importance of these properties in the first place. However, even if we grant that today's political agenda has indeed changed for the better, unless designers and critics understand that all of these properties, even when applied at the neighbourhood scale, are global not local, there is a danger that, with the test of time, some of today's radical, new designs might be judged to have 'got it wrong' once again, and that would be a disaster not only for the people who have to live there but also for architectural theory.

\footnotetext{
${ }^{*}$ Correspondence: Dr. Julienne Hanson, The Bartlett School of Graduate Studies, (Torrington Place Site), University College London, Gower Street, London WC1E 6BT, United Kingdom
}

\section{Streets and estates}

It is exactly one hundred years ago that the last rookery in London was demolished to make way for the first social housing estate designed by the newly-formed Architects' Department of 


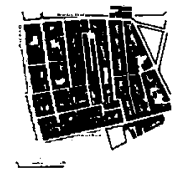

Figure 1 The Boundary Street area in the late 19th Century.

the London County Council. The rookery was the notorious Boundary Street slum, immortalised by Arthur Morrison in his sensational novel 'A child of the Jago' (1896), see Figure 1. The estate was Arnold Circus, and the LCC - later to become the GLC, the Greater London Council was eventually to become one of the most innovative, prolific and influential providers of mass housing in the English speaking world, see Figure 2.

The transformation in the urban fabric and in the streets, blocks, plots and buildings that make it up, recently described by one eminent planning historian as a mixture of 'the Parisian Boulevard la Haussman, the English Garden Village and a German town extension plan' (Smith Morris, 1997 , p. 44) is so dramatic that it is worth rehearsing the changes which are inscribed in the two maps. In the urban layout shown in Figure 1:

1. space is everywhere defined, integrated and put together by a continuous, open, shallow, accessible and highly-permeable system of streets which, with very few exceptions, form rings. This means that from any point in the system, there is more than one way through. As the street grid is traversed in any direction, the choice of which route to take expands in a direct relation to the length of the journey;

2. space forms a direct interface with the facades of the buildings, mainly houses, whose doorways give directly onto - that is, they 'constitute' - the streets. Everywhere we look, this direct relation of building entrances to streets is maintained. The continuous nature of constitution is a global property of the system as well as a local property of the individual streets;

3. the urban blocks form outward-facing islands, made up by terraces of individual, small houses which present their public face to the street and their private face to the interior of the urban block. Individual houses are aggregated directly together. They are as it were, 'glued together' by their party walls;

4. the morphology is robust. Individual houses, whole rows or even a complete urban block, can be easily demolished and replaced. The urban fabric is flexible and capable of absorbing local change;

5. it is a density-maximising morphology, the urban surface grows either by expansion at the urban edge to form new rings, or by intensifying the density of buildings in the backlands of existing blocks. The plan is first laid out and then filled in. In either case, the continuous open space structure is extruded alongside the buildings. The density of development increases over time;

6. although the individual buildings are quite similar to one another, each street segment is an unique intersection of open rings that interfaces with an unique set of buildings. Local regions of the urban surface are differentiated, though the rule structure which gave rise to it may be very parsimonious;

7. space is instrumental. It supports a rich mix of uses that includes workshops, sweatshops and small manufactories - usually in the backlands - everywhere intermingled with small shops and public houses - often at a street corner. It carries very little by way of social information of either a prescriptive or proscriptive kind;

8. space acts as a 'mixing mechanism' for both uses and people. Similar uses tend to cluster along a street frontage and to change at the turning of a corner, so that the different faces of the urban block accommodate different types of use, a phenomenon that we later called 'marginal separation by linear integration' (see Hillier, 1996, p 166).

In Figure 2, all these principles have been systematically inverted:

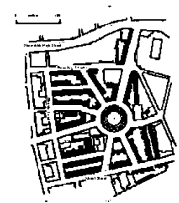

Figure 2 Arnold Circus housing estate. 
1. space is everywhere defined, separated and clarified by closed, bounded domains. Large segments of the open space are sealed-off by walls and railings, so that even though it is easy to see where to go, movement is channelled and the amount of real choice does not expand as the system is traversed. Even the paths through the open space have railings;

2. there is no longer a direct, permeable link between the facades of the buildings and the surrounding streets. Windows replace doors. Permeability is substituted by a visual link to the street. Often, street space is no longer defined directly by buildings. Instead, each block has a clear outer boundary or open space barrier, within which the buildings are then arranged as free-standing elements. Meanwhile, building entrances turn away from the street to face one another across a central, internal courtyard. The shift is from an outward-facing to an inward-facing morphology;

3. using the language of the 'generative' syntax set out in Chapter two of the Social Logic of Space, the change is from 'distributed' to a 'non-distributed' morphologies; that is, from $3 / 5 / 7$ syntaxes to $4 / 6 / 8$ syntaxes. In everyday language it is a change from 'gluing' to 'binding' as the means of aggregating spaces together. The defining feature of a nondistributed syntax is that it appears to be more permeable, though in most real cases this is just a trick of the eye, as permeability is curtailed by barriers restricting movement. Open space is rendered visually simple and unified, but inaccessible. The open space is bounded, frozen and full of rules, whilst inside, the blocks of dwellings take on the character a 'reversed building' with the residents in the deepest spaces and the caretaker in the shallower circulation system;

4. the fabric is therefore less capable of absorbing local change. Indeed, the very nature of the physical arrangements described above tend to resist piecemeal change at the level of the individual dwelling. Change has to be introduced by complete demolition and redevelopment;

5. it is a density-minimising morphology, where the open space dominates and controls the arrangement of the buildings. The whole is designed from the outset as a complete, geometric composition. The space that is released is frozen and cannot be built on or used. The system can only grow by designating new urban blocks with clear boundaries;

6. spaces are more alike, despite the distinctiveness of the architecture, a reversal of the previous situation where the buildings were alike but the streets were all different. Here, local regions of the urban surface seem similar to one another, usually as a result of an hierarchical and global geometry that controls the entire layout and which is indifferent to factors like orientation or topography. This is a from 'structure' to 'order', distinction, first published in a special issue of Ekistics devoted to 'space syntax' in 1989, as 'Order and structure in urban design: the plans for the rebuilding of London after the Great Fire of 1666' (Hanson, 1989). The order is exogenous rather than endogenous;

7. space is expressive, labelled and rule-governed. There is a build-up in the ideology and the meaning of spaces by the use of names and symbols, and by rules to restrict non-conforming behaviours: no ball games, no hawkers, no loitering, no pets. There is an avoidance of randomised events and unprogrammed behaviour. Instead, space is loaded with social information, much of it of a prescriptive or proscriptive nature;

8. space acts as a 'filter'. Its purpose is to separate people and to clarify functions. All of the spaces are labelled for specific activities. In short, space is zoned for both uses (residential only) and for people (inhabitants only).

\section{All these changes are summarised in Table 1.}

These eight points which describe the extent of the first urban transformation, can be encapsulated in just two words; 'street' and 'estate'. Paradoxically, this completely inverts the original meaning of the term 'estate' from its earlier use, during the eighteenth century, to describe the achievements of Georgian town planners in the 'great estates' which transformed to the West End of London after the Building Act of 1744, the four principles of which were set out by Samuel Pepys Cockrell (reported in Summerson, 1962, pp.167168), the architect for the Foundling Estate, as follows: 
Table 1

\begin{tabular}{|c|c|c|}
\hline & Before & After \\
\hline 1 & $\begin{array}{l}\text { Continuous street space, open, shallow, } \\
\text { expanding, integrating and overlapping }\end{array}$ & $\begin{array}{l}\text { Fragmented estate space, bounded, deep, enclosed, } \\
\text { segregating and hierarchical }\end{array}$ \\
\hline 2 & $\begin{array}{l}\text { Direct interface, streets continuously } \\
\text { constituted by front doors }\end{array}$ & $\begin{array}{l}\text { Indirect interface, streets lined by } \\
\text { boundaries with few entrances }\end{array}$ \\
\hline 3 & $\begin{array}{l}\text { Outward-facing morphology, buildings } \\
\text { front onto streets }\end{array}$ & $\begin{array}{l}\text { Inward-facing morphology, buildings } \\
\text { back onto streets }\end{array}$ \\
\hline 4 & $\begin{array}{l}\text { Flexible, robust morphology, } \\
\text { absorbs change }\end{array}$ & $\begin{array}{l}\text { Inflexible, brittle morphology, } \\
\text { resistant to change }\end{array}$ \\
\hline 5 & $\begin{array}{l}\text { Density-maximising morphology, } \\
\text { streets carved out of the solid }\end{array}$ & $\begin{array}{l}\text { Density-minimising morphology, } \\
\text { pavilions in a landscape }\end{array}$ \\
\hline 6 & $\begin{array}{l}\text { Organic morphology, streets laid out and } \\
\text { filled-in leading to unique street segments }\end{array}$ & $\begin{array}{l}\text { Geometric morphology, blocks laid out and joined by paths, } \\
\text { leading to repetition }\end{array}$ \\
\hline 7 & Instrumental space & Expressive space \\
\hline 8 & $\begin{array}{l}\text { Space of social production, bottom-up } \\
\text { process, space acts as a mixing mechanism }\end{array}$ & $\begin{array}{l}\text { Space of social reproduction, top-down process, } \\
\text { space fixes events and behaviours }\end{array}$ \\
\hline
\end{tabular}

1. accommodation for all classes;

2. streets and squares with planted gardens;

3. continuity with the adjoining urban fabric;

4. a plan capable of gradual execution.

Then 'estate' stood for 'street system'; today it stands for its morphological antithesis.

Of course, the urban transformation that was realised by this first state housing estate did not spring fully-fledged from nowhere. The ideas had been fifty years in the making. One of the earliest inward-facing morphologies in the record, and one of the most influential and best-publicised philanthropic housing schemes for the workingclasses, was Henry Roberts' Model Housing for Families' at Streatham Street, Bloomsbury (184750). It almost goes without saying, that the contemporary, fashionable mansion flats of middle-class Bloomsbury residents were built as outward-facing, street-oriented morphologies.

Nor did all the early model housing turn its back so obviously to the street: some small schemes were built as walk-up flats with an entrance from the street, others favoured outward-facing balcony access, but the majority opted for the more controllable courtyard form. However, by the 1860s, Henry Darbishire, the architect for the largest of the philanthropic housing companies, the Peabody Trust, was master-planning large rectangular urban sites as arrangements of 'simple, clean-shaped blocks, without re-entrant angles, facing the street on the one side and a large private court on the other' (Tarn, 1969, p. 21) as the most healthy, affordable and safe way to house the urban labouring classes. The agenda for the first urban transformation had been set.

Time does not permit us to follow the many innovations and developments within the housing portfolio of the architects' department of the LCC/GLC up until its eventual disbandment in 1986. That is another story. But then we do not really need to, because the housing that we shall examine next, in the Somers Town study, is a microcosm of how the design of public authority housing estates has evolved in just about every town and city in the UK. It is a story of continuity and change in the morphology of high-density, low-rise, inner city housing estates, a solution to mass housing that, in the concluding paragraphs of the 'Social Logic of Space' (Hillier and Hanson, 1984, pp. 266-268), we described as the 'hard solution' because of its physical power to coerce:

'the classic form of the modern estate, with its outer boundary, open-space barriers, few entrances, separate blocks, and separate staircases, is the very paradigm of the solution...which was, under the guise of a new technology, to sweep the world in the mid-twentieth century, becoming as universal a form of space as distributed street systems were in the previous society.' (Hillier and Hanson, 1984, p. 267),

We suggested, in the Social Logic of Space, that the 'hard solution' became so ubiquitous because it seemed to offer a simple way to ensure a stable 
social order in the rapidly-urbanising slums of the inner cities, but that in its spatial power simultaneously to concentrate and to separate, lay the seeds of its own destruction. It is certainly the form of architecture which, perhaps more than any other, has given architecture in the UK a bad name so that, today, the power to build social housing has effectively been removed from the local authorities and state agencies and placed in the hands of housing associations that are supposedly more user-centric. However, the spatial legacy of the 'hard solution' remains as, indeed, do many of the ideas that gave rise to it.

With this in mind, the next step is therefore to set out some detailed evidence of the sort of spatial changes that took place, using Somers Town as a case study to illustrate how the 'hard solution' has evolved during the course of the twentieth century. It is important to bear in mind as this story unfolds, that this was a solution that wellmeaning professionals inflicted on the urban poor, those who could not, or would not, or were not allowed to house themselves and so were perceived to need extra help from the state; that, despite its prominence in the architectural literature, the estate was not and is not a middle class morphology; and that housing estates constitute just a small fraction of the total housing stock.

\section{The urban zoo}

Figures 3 and 4 show two maps of Somers Town, the first from the 1890s and the second from the 1990s. If the layouts seem familiar, this is not just because they resemble those of the urban transformation at Boundary Street, but also because the highlighted area in the top left of each illustration was originally shown in Chapter 3 of the 'Social Logic of Space' that was devoted to the analysis of settlement layouts. These maps enlarge the area covered by those earlier drawings, to include the whole of Somers Town.

The Somers Town neighbourhood is an area of about $1000 \mathrm{~m}$ north-south by $500 \mathrm{~m}$ east-west, located immediately to the north of London's busy Euston Road. It is bounded to the west by Eversholt Street and the impermeable bulk of Euston Station (1838), to the east by St Pancras Way and St Pancras Station (1868), to the south by

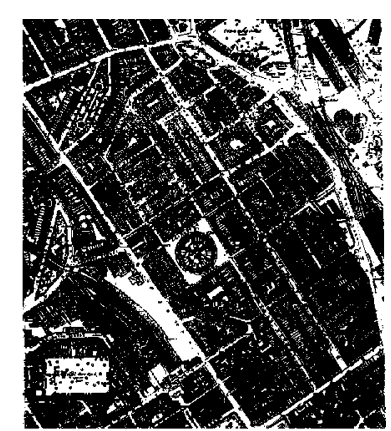

Figure 3 The map of Somers Town in the 1890s.

the Euston Road which, as the New Road from Paddington to Islington, defined the northern limit of London in the mid 1700s, and to the north by Crowndale Road and Oakley Square, which have marked the southern extent of the more fashionable district of Camden Town since the late eighteenth century.

The area took its name from the first Lord Somers of Evesham who owned the land on which the new 'town' was developed by the speculative builder Jacob Leroux after 1786 (Summerson, 1962, p. 281). The first housing built on what had previously been open fields was the unusual Polygon of 1784, which Summerson describes as 'a kind of inverted circus, composed of detached blocks of houses facing outwards and having courts or gardens running to the centre' (p. 282). It was aimed at the middle classes who were flocking to the new streets and squares that were being laid out nearby in Bloomsbury, to the south of Euston Road, during the 1770 s and 1780s. However, neither the Polygon nor Somers Town proved popular with the wealthy residents for whom it had originally been intended, and so the land was eventually sold off in smaller plots to more 'down-market' house builders. Morphologically

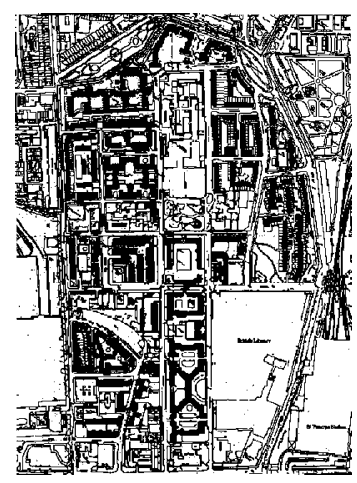

Figure 4 The map of Somers Town in the 1990s. 
speaking, the area began life as a classic street system.

Somers Town became a refuge, first for many of the 40000 Huguenot refugees from the French revolution, for immigrants from Italy and Spain, and then for Irish navvies who were drawn to London in large numbers in the mid-nineteenth century by the construction of the railways. The building of the nearby stations both attracted large workforces into the area and displaced large numbers of local people from their homes. Rundown and overcrowded, Somers Town soon acquired the reputation of providing a source of cheap housing for manual labourers and immigrants and of being a hot-bed of social unrest and discontent, an image which it still retains today. Then, as now, it supported a rich mix of housing and local industry, several churches of a variety of religious denominations, a street market and many public houses. Socially inferior to London's 'great estates' that were growing up in the West End during the eighteenth century under the patronage of the aristocracy, the 'town' had a clear topographical identity: small-scale, close-knit and rather cut-off from its surroundings. Yet whilst Somers Town never acquired the notoriety of the Jago, it was sufficiently close to middle class housing area and university precinct of Bloomsbury for the poor state of its housing to give rise to concern.

The area began to be transformed in the closing decades of the nineteenth century. The first model housing, by the Metropolitan Association for Improving the Dwellings of the Industrious Classes, was erected in 1848 and was therefore contemporary with the Streatham Street block, but it did not survive the devastation of World War II. The oldest extant model dwellings, dating from the 1890s, are on Cranleigh Street. St Pancras Council began slum clearance and rebuilding in 1906 and was joined by the charitable St Pancras Housing Association after 1924. The LCC initiated its own rebuilding programme in Somers Town in 1901 and became an active provider of state housing after 1927, so that today, almost nothing survives of the earlier Georgian housing. Somers Town is now a landscape of housing estates. In their day, almost all of the new estates were described as innovative, progressive or even idealistic.

Some things remain unchanged today after a century of redevelopment. The building density has actually reduced, the building height remains at about four storeys and the principal building material is brick. Just like its modern counterpart, the original 'town' was built using early standardised components and industrial processes in order to minimise the capital costs of building. Today, Somers Town still plays host to a wide variety of urban uses. The new British Library takes up the entire south east corner of the area, and a mix of uses including a theatre, library, hospital and fire station front onto the Euston Road. Eversholt Street is lined with shops and offices, and there is still a scatter of light industrial premises, especially in the south of the area. The street market and most of the pubs have survived, as have a few blocks of the original terraced housing. The north of Somers Town is more solidly residential, but split into two by schools and playgrounds.

The social reputation of the area has not changed for the better, despite its having been almost entirely redeveloped. Most local residents (92\%) still rent their homes, either from the local authority $(63 \%)$ or from a housing association $(23 \%)$ or private landlord $(6 \%)$. Only $8 \%$ of residents are owner-occupiers. The houses are still run-down (15\% of the stock) and overcrowded $(20 \%)$. Car ownership is low ( $27 \%$ of households). The area has high numbers of older people $(15 \%)$, young people $(21 \%)$, unemployment $(22 \%)$ and people who are incapacitated by a limiting long term illness (33\%). It is a multicultural neighbourhood with only $74 \%$ white residents. Of these, $8 \%$ are of Irish origin, a relic from the days of the navvies. The rest are from the ethnic minorities, including Bangladeshis (13\%), Black groups (7\%) and other Asian groups (5\%), supplemented by a small number of ethnic Chinese and Somalis. Crime is considered to be a major problem by local residents (31\%). Antisocial and threatening behaviour, including racial and sexual harassment, and drug trafficking are also perceived as a problem, so that many residents $(43 \%)$ feel unsafe going out after dark. One in ten residents is actually deterred from going out at all at night, and among pensioners this figure is more like one third. (Ian Haywood Partnership, Somers Town Community Safety Project, May 1997, p. 1-2). Whichever way you look at it, Somers Town is home to large numbers of people who have few of life's advantages, and the area still feels rather run down and neglected, 
Table 2

\begin{tabular}{|c|c|c|}
\hline Pre-1899 & 1 & Late 19 th century model walk-up flats \\
\hline \multirow[t]{3}{*}{$1900-1924$} & 2 & LCC street-oriented but set back housing blocks of walk-up flats \\
\hline & 3 & LCC inward-facing courtyard housing, in blocks of walk-up flats \\
\hline & 4 & Gaunt, court-orientated, balcony-access flats \\
\hline \multirow[t]{7}{*}{$1925-1949$} & 5 & $\begin{array}{l}\text { First model dwellings by the then St Pancras House Improvement Society, } \\
\text { now the St Pancras Housing Association }\end{array}$ \\
\hline & 6 & $\begin{array}{l}\text { The Ossulton Estate, combining formal street facades with shops on two sides, } \\
\text { arched entrances to courtyards where the entrances to dwellings are centrally-placed } \\
\text { in the facades to the internal courtyards and approached by flights of steps and balconies }\end{array}$ \\
\hline & 7 & $\begin{array}{l}\text { St Pancras Housing Association kraal-form, where access is mainly by flights of stairs } \\
\text { in the archways that link the courtyards or at the corners of blocks }\end{array}$ \\
\hline & 8 & A simple and stark courtyard, detached part of the Ossulton Estate \\
\hline & 9 & Exuberant, Art Deco high-style eight storey high walk-up blocks \\
\hline & 10 & $\begin{array}{l}\text { Plain eight storey walk-up perimeter planning on the northern boundary with Crowndale Road, } \\
\text { with a boundary and estate road }\end{array}$ \\
\hline & 11 & High-density outward-facing but set back, railed-off balcony-access \\
\hline \multirow[t]{3}{*}{$1950-1969$} & 12 & A small slice of suburbia, in the form of a row of small, semi-detached and terraced two storey cottages \\
\hline & 13 & An L-shaped block of balcony-access flats \\
\hline & 14 & Early post-war, plain balcony-access flats \\
\hline \multirow[t]{6}{*}{$1970-1989$} & 15 & $\begin{array}{l}\text { Landscaping of the earlier LCC blocks, also to break up the external space within the courtyards } \\
\text { and provide a layer of 'semi-private' space close to the building entrances }\end{array}$ \\
\hline & 16 & $\begin{array}{l}\text { An early 'urban village' solution, based on a new interpretation of a high density, } \\
\text { low-rise 'streets and squares' morphology }\end{array}$ \\
\hline & 17 & $\begin{array}{l}\text { A housing association street look-alike to complete an urban block of original terraced houses } \\
\text { with set back entrances and a view of the street substituted for street access, but no outer boundary }\end{array}$ \\
\hline & 18 & $\begin{array}{l}\text { A small, labyrinthine L-shaped 'court', that attempts a complex and articulated traditional street } \\
\text { within the middle of the block whilst preserving a solid outer boundary to the surrounding streets }\end{array}$ \\
\hline & 19 & $\begin{array}{l}\text { Oakshott Court, built on the site of the Polygon, an anti-axial, formalistic, stepped L-shaped block } \\
\text { with a complex section and hard outer boundary }\end{array}$ \\
\hline & 20 & $\begin{array}{l}\text { An informal 'village', with a layout and style that pays architectural homage } \\
\text { to the well-publicised Marquess Road, Islington }\end{array}$ \\
\hline \multirow[t]{2}{*}{ post-1990 } & 21 & $\begin{array}{l}\text { A refurbishment of the } 1926 \text { St Pancras scheme, that turns the access inside-out, } \\
\text { to create an outward-facing morphology, one of many that are now taking place in Somers Town }\end{array}$ \\
\hline & 22 & A new, 1990s terrace of outward-facing but 'fortified' houses \\
\hline
\end{tabular}

despite the many 'improvements' that have been made to the local environment.

Physically, however, from being a rather bland and nondescript area replete with small London terraced houses, Somers Town is now rather like a 'housing zoo'. Packed into its small area is at least one specimen of just about every 'species' of twentieth century social housing. At first sight, the collection of modern housing environments appears very heterogeneous: some layouts are geometric while others are informal; some have adopted a distinctive 'high-style' architecture, others appear nondescript and anonymous. The physiognomy of the area has completely changed but, if anything, it seems to have become even more varied than before (see Table 2). There are now about twenty two social housing schemes in Somers Town, which have been listed roughly in date order and placed in six bands that represent the major construction cycles. Taken as a set, the new housing estates in Somers Town hold up a mirror to changing tastes in architecture over the course of this century. Some sites have been redeveloped more than once and most have been refurbished to follow changing architectural fashions.

The quantitative analysis which follows is based on seventeen of these twenty-two species. Schemes 1, 12, 17, 21 and 22 have been omitted as these are outward-facing, street-orientated morphologies, not estate layouts. The figures that accompany the analysis are illustrative, and refer to the estates that are highlighted in bold in Table 2. These are the six schemes from the northwest quadrant of Somers Town that formed the basis of the original analysis which allowed us to 
Table 3

\begin{tabular}{lll}
\hline & \multicolumn{1}{c}{ Measure } & \multicolumn{1}{c}{ Definition } \\
\hline 1 & Maze index & The mean depth of the axial system from the surrounding streets \\
2 & No-neighbours score & The mean depth of the convex system from the dwelling entrances \\
3 & Separation index & The mean depth of surrounding streets from the nearest dwelling entrances \\
4 & Constitutedness rate & The percentage of convex spaces that are constituted by dwelling entrances \\
5 & Neighbourliness score & The average number of dwelling entrances per constituted convex space \\
6 & Interface decomposition score & The mean steps between dwellings in the shortest path that links all dwellings in \\
& & the layout together \\
\hline
\end{tabular}

formulate the ingredients of the 'new (modernist) urban genotype', way back in 1979. In what follows, our interest will begin to turn from the larger street system to the interiors of the urban blocks for, contrary to appearances, we shall see that it is here and not in the global urban system, that the substantive urban transformation has taken place.

Quantitative analysis of the layouts will concentrate on six previously unpublished simple 'syntactic' measures that have been designed specifically to explore the urban transformation from 'street' to 'estate' layouts, see Table 3. The first measure is based on the familiar axial representation of space and the remaining five on the little-used (at least so far as urban analysis is concerned) convex representation of space.

Four interface maps (see below for details of how

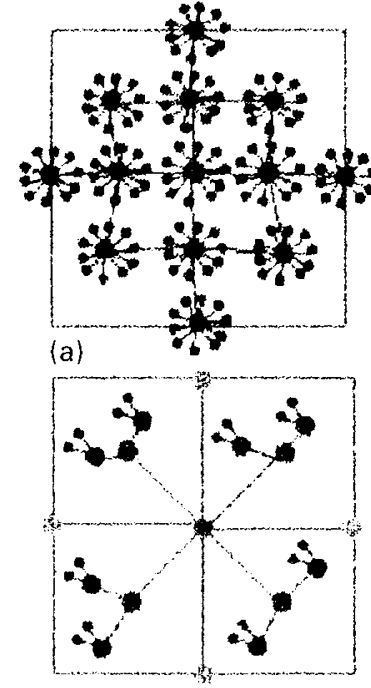

(c)

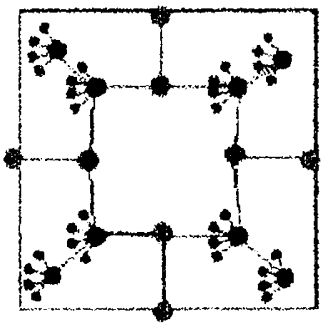

(b)

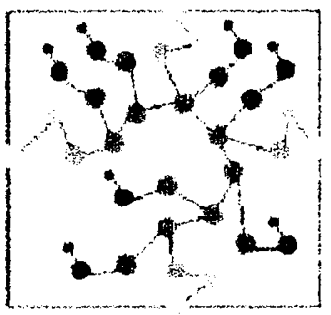

(d)
Figure 5 Four hypothetical layouts. to construct this representation) of 'hypothetical layouts' with different syntactic features are illustrated in Figure $5 a-d$, in order to give a feel for how the various measures perform. The greyscale tones represent steps of convex depth away from the front doors of the dwellings, shown as black dots, from dark grey - depth one - to palest grey - six steps away. Table $4 \mathrm{a}-\mathrm{d}$

Table 4a

\begin{tabular}{llr}
\hline $\mathbf{5 a}$ & \multicolumn{1}{c}{ Measure } & Value \\
\hline 2 & No-neighbours score & 1 \\
3 & Separation index & 0 \\
4 & Constitutedness rate & $100 \%$ \\
5 & Neighbourliness score & 10 \\
6 & Decomposition score & 1 \\
\hline
\end{tabular}

Table $4 b$

\begin{tabular}{clc}
\hline $\mathbf{5 b}$ & \multicolumn{1}{c}{ Measure } & Value \\
\hline 2 & No-neighbours score & 1.5 \\
3 & Separation index & 3 \\
4 & Constitutedness rate & $50 \%$ \\
5 & Neighbourliness score & 4 \\
6 & Decomposition score & 1.875 \\
\hline
\end{tabular}

Table 4c

\begin{tabular}{llc}
\hline $\mathbf{5 c}$ & \multicolumn{1}{c}{ Measure } & Value \\
\hline 2 & No-neighbours score & 1.462 \\
3 & Separation index & 4 \\
4 & Constitutedness rate & $61.5 \%$ \\
5 & Neighbourliness score & 2 \\
6 & Decomposition score & 1.625 \\
\hline
\end{tabular}

Table 4d

\begin{tabular}{llc}
\hline $\mathbf{5 d}$ & \multicolumn{1}{c}{ Measure } & Value \\
\hline 2 & No-neighbours score & 2.690 \\
3 & Separation index & 6 \\
4 & Constitutedness rate & $24.1 \%$ \\
5 & Neighbourliness score & 1 \\
6 & Decomposition score & 3 \\
\hline
\end{tabular}


inclusive shows the new convex measures calculated for each hypothetical layout.

The measures will be applied first to the main street grid of the Somers Town area, which will benchmark the area as it was and is today, and then to the interior layouts of each of the seventeen estates to see if any or all of the measures have changed over time as the area has been transformed into an urban 'estate' physiognomy. In addition to the new measures, the account will comment on the distribution of axial lines of different lengths in relation to front doors and the surrounding streets, and the shape, size and distribution of convex spaces, also with respect to front doors and the surrounding streets.

\section{Modernist urban space}

Right from its inception in the early decades of the nineteenth century, whilst Somers Town was still being built and it was at the very edge of the growing metropolis, the area was linked into the urban grid by long, strong axial lines which connected it back into the urban tissue. The 'open space' map of Somers Town that was taken from the Ordnance Survey map of the late nineteenth century, see Figure 6, shows more clearly the layout of the urban grid at the peak of its original development. For the most part, the street grid was regular and made up of many small, denselypacked, rectangular urban blocks that were replete with backland development. There was very little open space, and a secondary system of courts and alleys had developed to serve the buildings in the heart of the urban blocks.

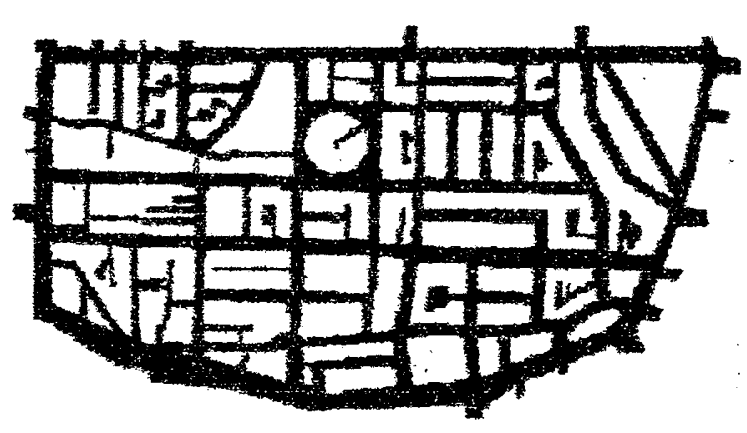

Figure 6 Open-space map of Somers Town in the late 19 th century.

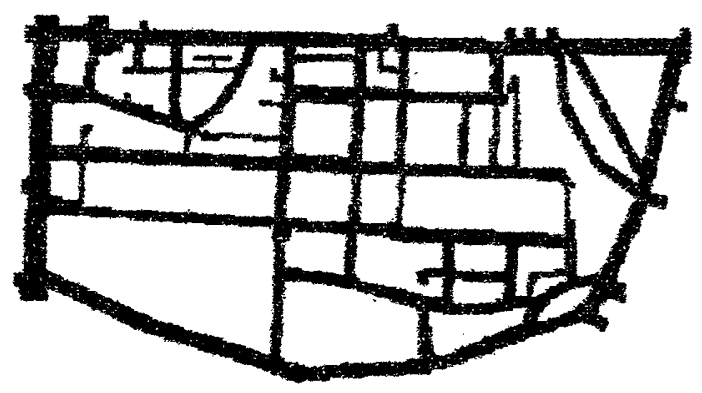

Figure 7 Open-space map of Somers Town in the late 20th century.

Figure 7, shows the area as it is now, in the 1990s. The major street grid remains more or less unchanged and we can recognise the residue of historical layering that is perpetuated in the modern map. There are fewer and larger islands, formed by the amalgamation of adjacent urban blocks, and the area is more cut off than before from Camden Town to the north, but elsewhere the traces of the original street layout are clearly visible in the orientation of the roads and the shapes of the urban blocks.

Even today, Somers Town has not experienced the degree of segregation that is characteristic of so many of the large, modern housing estates in the area. As we have already seen, the local street grid is simple and shallow and the surrounding roads act as effective intermediaries that linking into London's arterial road network so that, even within the global London context, see Figures 8 and 9, Somers Town is less isolated than its immediate local circumstances - wedged between two great railway termini - might lead one to expect.

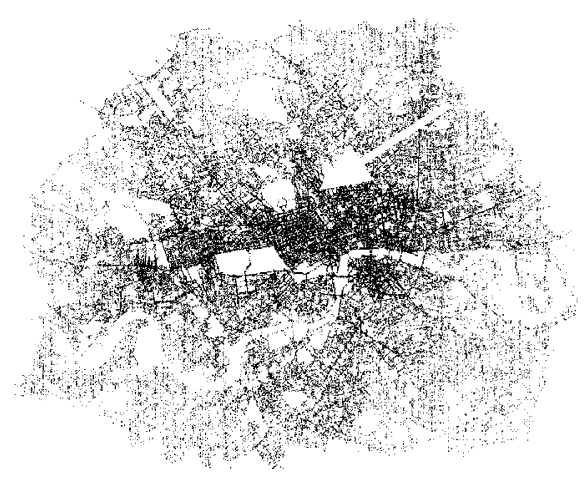

Figure 8 Axial analysis of London in the late 20th century showing the Somers Town area. 


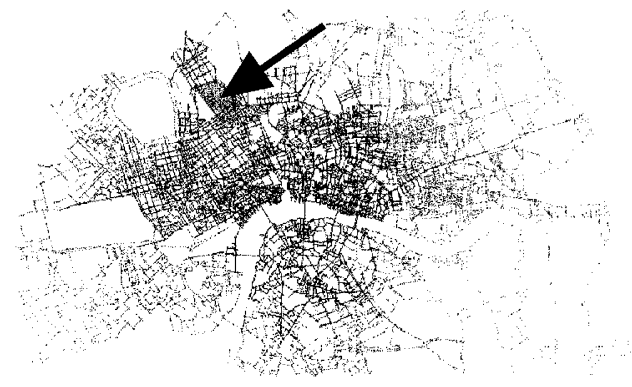

Figure 9 Axial analysis of London in the early 19th century showing the Somers Town area.

What is less clear from the open space maps is that the area has also undergone the classic eight point urban transformation that was described earlier, and which can be summed up in yet another pair of drawings taken from the Social Logic of Space, this time showing the 'interface' between the streets and the buildings which 'constitute' them, see Figures 10 and 11. To produce these 'interface maps', the convention was adopted of representing each individual building as a black dot, each convex street segment as an open circle and each bounded, railed-off estate as a black dot with a circle attached to it, to represent the enclosed open space in which it sits. The permeable interface between the buildings, open spaces and streets was then shown by lines joining the dots, including only those surfaces that are immediately adjacent to the street so as to define the perimeter of each urban block. All the entrances between the buildings or bounded open spaces were shown as a line linking dots to circles, but the position of any buildings that are set within the estate space, and which therefore do not construct a direct relation with the street, was disregarded. The drawings show just the northwest sector of Somers Town identified earlier.

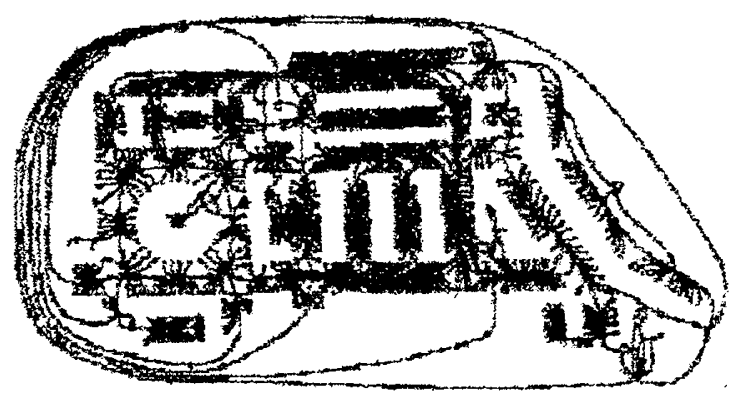

Figure 10 Interface map of 19th century Somers Town.

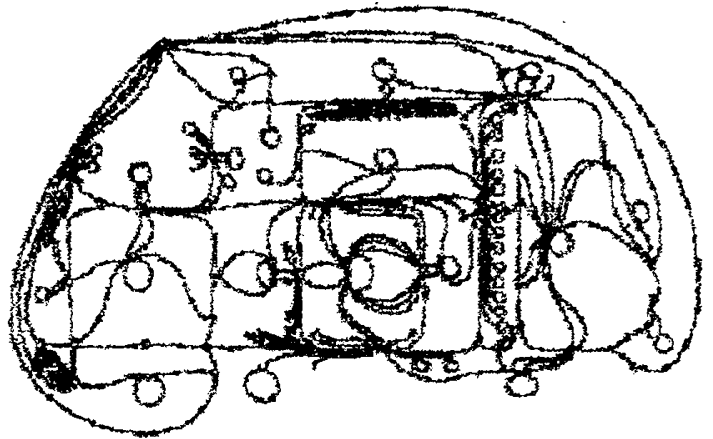

Figure 11 Interface map of 20th century Somers Town.

The production of these representations was a defining moment for 'space syntax', for the drawings seemed to capture the shift from a dense to a sparse urban surface more graphically than any narrative. With rather few exceptions, the traditional streets were everywhere convexly shallow to building entrances so that streets were continuously constituted by literally dozens of doors. Although the new street grid had looked pretty much the same as before, the drawings showed that the constitution rate had dropped dramatically to just a handful of entrances, and these were not to buildings but to the bounded open spaces in which each estate was set.

The practical consequence for a pedestrian in Somers Town today is that for most of the time he or she is walking adjacent to the open spaces of estate layouts that are sealed off from the streets by their secondary boundaries, not next to the facades of buildings and their doorways. At the same time, deep inside each island of space defined by the streets, where previously there were private gardens and back alleys, the open 'estate' space that is trapped inside the boundary has become much more extensive and elaborate.

The extent of the morphological changes that have occurred in the main street grid is summarised in Table 5.

In line with what we now know about the growth of large cities (Hillier, 1996, pp. 360-368) we can see from Table 5 that the primary street grid has become coarser, shallower and more integrated over time. The number of island blocks has nearly halved, and so has the number of axial lines. The ratio of through streets to culs-de-sac has just about doubled. However, the local 'maze index' has hardly changed at all. The area was, and is, 
Table 5

\begin{tabular}{lcc}
\hline Morphological property & $\mathbf{1 8 9 0 s}$ & $\mathbf{1 9 9 0 s}$ \\
\hline Total island blocks & 60 & 34 \\
Total axial lines in system & 94 & 54 \\
Depth 1 from supergrid & 33 & 19 \\
Depth 2 from supergrid & 47 & 26 \\
Depth 3 from supergrid & 12 & 7 \\
Depth 4 from supergrid & 3 & 2 \\
Maze index for Somers Town & 1.862 & 1.852 \\
Distributed/through street & 68 & 45 \\
Nondistributed/cul-de-sac & 26 & 9 \\
Distributed: nondistributed ratio & $2.615: 1$ & $5.000: 1$ \\
Total convex spaces in system & 347 & 87 \\
Constituted & 328 & 21 \\
Depth 2 & 19 & 25 \\
Depth 3 & 0 & 23 \\
Depth 4 & 0 & 16 \\
Depth 5 & 0 & 2 \\
No-neighbours score & 1.055 & 2.460 \\
Separation index & 0 & 3.211 \\
Constitutedness rate & $94.5 \%$ & $24.1 \%$ \\
Neighbourliness score & 21.721 & 4.281 \\
Interface decomposition score & 1.000 & 1.167 \\
\hline
\end{tabular}

quite shallow and integrated. It used to be possible to cross right through the middle of Somers Town in both an east-west and a northsouth direction in one axial step. Today, the north-south route requires a minimum of three or four steps, but other parts have become locally much more simple to navigate.

The convex measures show more evidence of change. The convex articulation of the grid in the 1900 s is only a quarter of what it was in the 1890s, showing just how much the street lines in the area have been regularised and 'ironed out'. The spaces that remain are longer, more rectilinear and closer in shape to the axial lines that run through them than the previous arrangement of 'beads' of space strung together (see Hillier and Hanson, 1984, pp. 57-61). Now, only $24.1 \%$ of those spaces are directly constituted by people's front doors, the 'constitutedness rate', compared with $94.5 \%$ before, and there are far fewer dwellings on the spaces that are left. The 'neighbourliness score' has dropped from over twenty entrances per convex space to just below five.

Meanwhile, many more bounded spaces interpose themselves between the spaces with front doors, raising the 'no-neighbours score' from just above 1 (the absolute minimum) to nearly 2.5 . The 'separation index' tells us that when walking through a blank-walled space, the nearest front door is, on average, three convex spaces away.

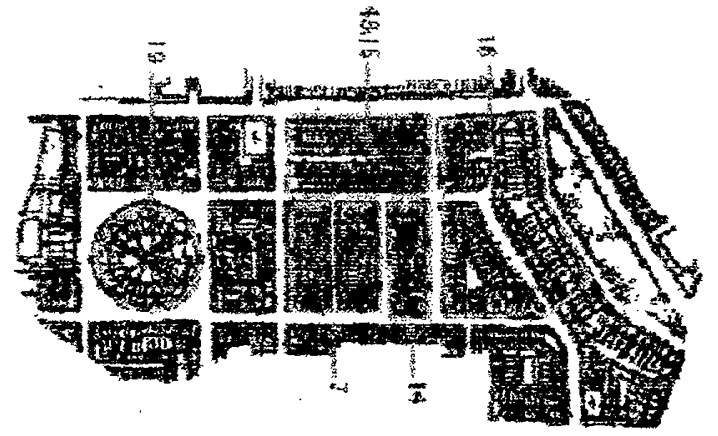

Figure 12 Somers Town before the transformation.

The 'decomposition score' has also risen above 1, (the minimum), but not by much. This tells us that the fragments of street grid that are left are not scattered indiscriminately everywhere, but are clustered nearby one another, in the north-east and the south-west to be precise, so that, by using local knowledge it is possible to select a route through the area which still manages to keep in close touch with people's front doors.

These effects can be explored further by looking in detail at how redevelopment has affected the layout of each of the housing estates inside its outer perimeter boundary, and then at how changes in the appearance of the layout can also be captured in the measures.

\section{Exploring estate layouts}

Figure 12 shows the set of urban blocks for the six illustrative schemes before redevelopment and Figure 13 shows the same blocks after redevelopment Figure 12, illustrates in more detail the features of street layouts that were shown and quantified in the earlier 'benchmarking' exercise. Figure 13, shows the plan of each of the estates that has replaced each island block or set of urban

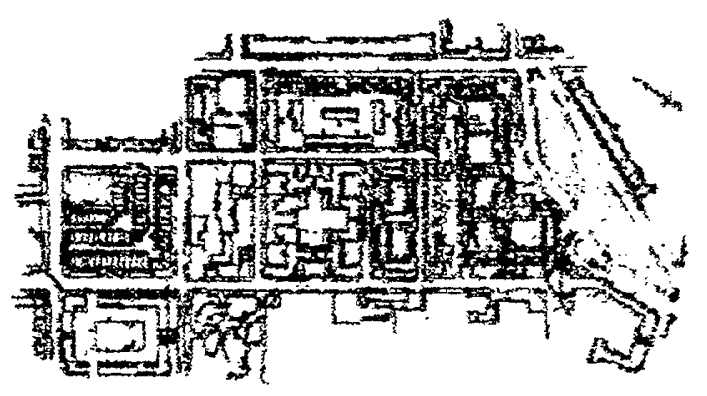

Figure 13 Somers Town after the transformation. 
blocks, with all the entrances to dwellings indicated. Note that in everything that follows, all the dwellings above the ground floor will be disregarded, so that we can concentrate on the experience of a pedestrian moving around on the estate.

Figures 14 and 15 then separate the building 'footprints' for each of the estates in the northwest sector from the open space maps, which show all of the 'walkable' space inside each estate. Some spaces do not show up on either of these representations because they are spaces which are railed-off and so cannot be walked on, such as the flower beds, green spaces or light wells. Though we see here only the six maps that correspond to the six street areas opposite, Figure 16 shows the aggregate effect of all seventeen estates on the morphology of Somers Town. This map includes all the estate space that is accessible to visitors or people passing through. Although the map cannot reproduce all the fine detail of each morphology, we can immediately see that the layouts are as varied as the architectural styles in which the various estates have been built. Analysis of each estate is based on a more detailed version of its respective open space map.

The next step is therefore to construct an axial map and a convex map for each estate, on the basis of its open space map. Figure 17 shows the axial map for each of the schemes illustrated. The 'box' in which each estate 'sits', is the set of its surrounding streets. The axial depth of each line from the street grid is indexed in greyscale from black - step one - through darker grey tones steps two and three - to paler grey tones - steps four and five - to light grey tones for the deepest spaces of all. Note that this time, the tones are not showing bands of integration but steps of depth. This is a graphic representation of the 'maze index', which can then be quantified by calculating the mean depth of all the estate lines from the surrounding streets. Sociologically, axiality might be considered to reflect more a visitor's dimension of the system, as it provides information about what lies ahead and how to find one's way. The 'maze indices' for all seventeen estates in Somers Town are set out on the right in Table 6 . The lower the index, the more shallow and inviting the layout, the higher the index the more labyrinthine and intimidating.

The first measure, giving the number of axial lines
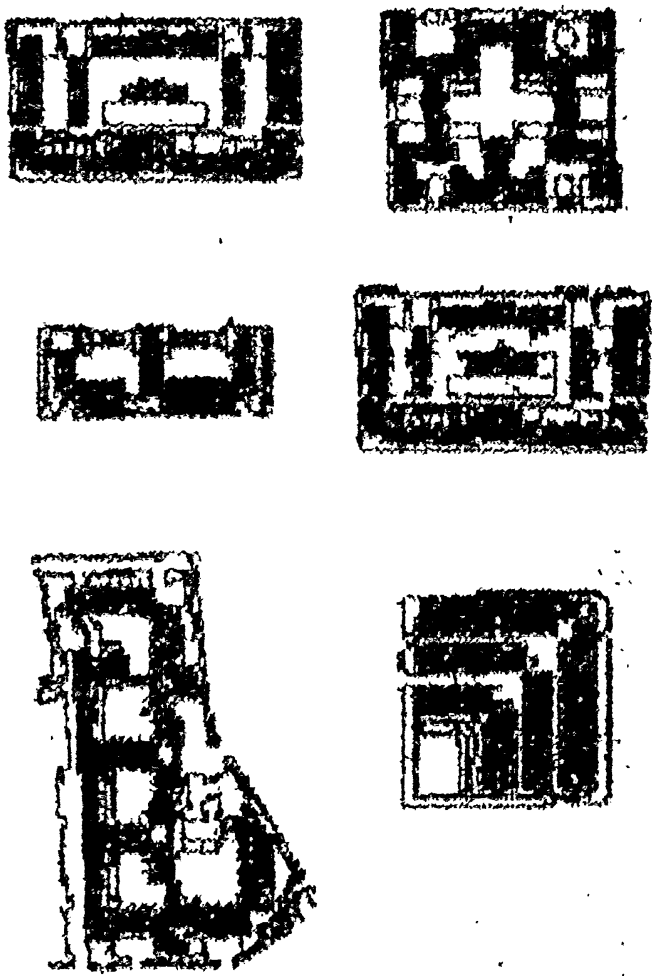

Figure 14 Building 'footprints'
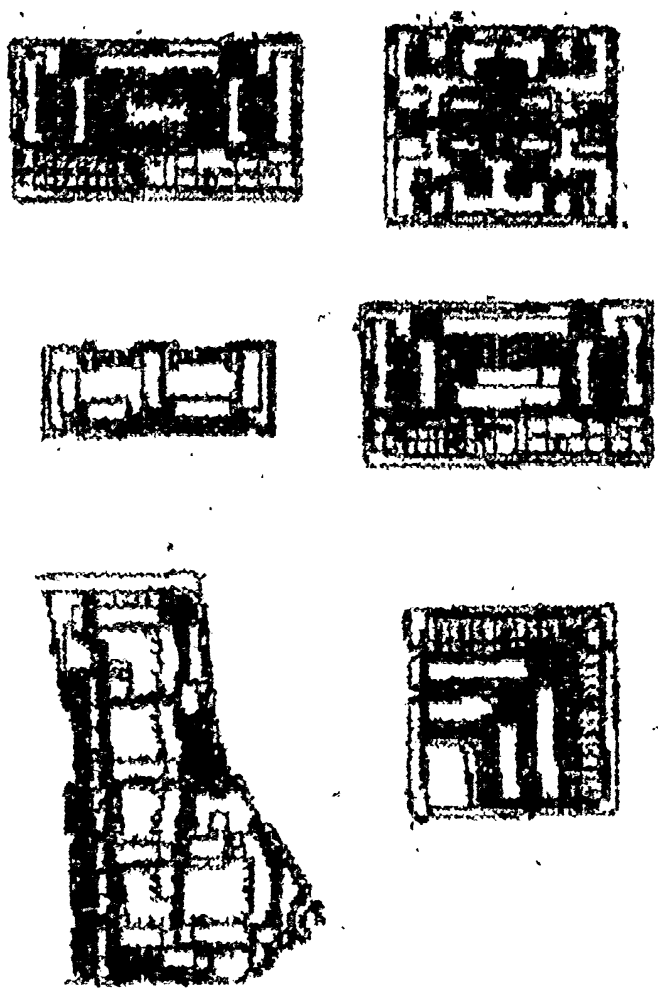

Figure 15 'Open-space’ map. 


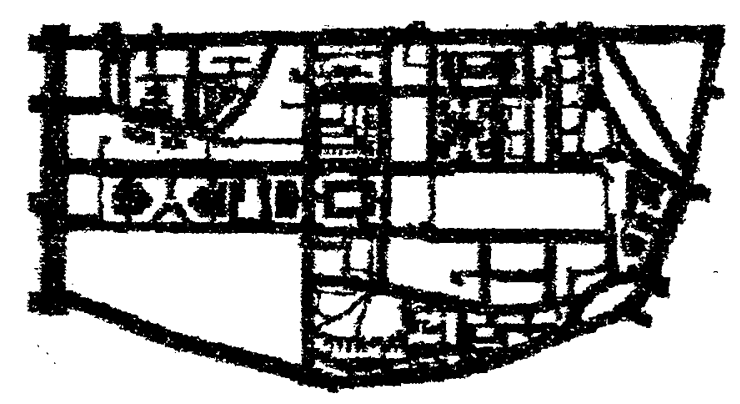

Figure 16 Aggregate open-space map of Somers Town.

for each layout, cannot strictly-speaking be directly compared, because the figures relate to layouts of different metric areas. What is clear is that, whatever their size, the estates introduce a new dimension of axial complexity to Somers Town. Layout 19, on the site of the former Polygon, with 78 axial lines is axially almost as elaborate as the whole of Somers Town was in the 1890s, (94 lines). One urban block has miniaturised and reproduced the complexity of an entire urban neighbourhood. Despite the small numbers of layouts in this study, miniaturisation of the local interior grid is a feature that we have encountered many times in estate layouts, particularly of the recent past, so that we can be fairly secure in noting it as a property of modern estate layouts.
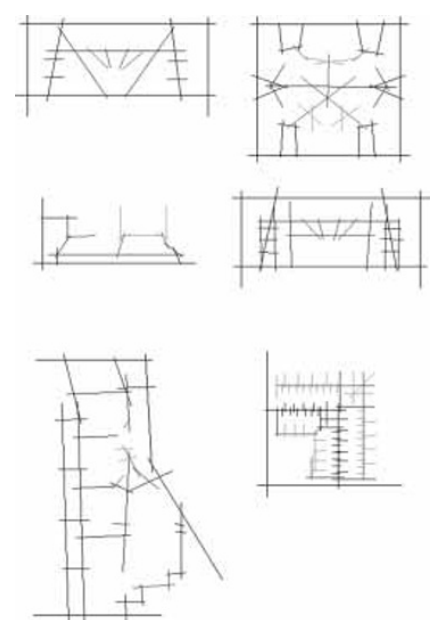

Figure 17 Axial maps of the six estates.

We can explore this further by taking the mean number of axial lines for all four time bands for which we have estates, 25 lines, and setting this against the mean for each band. This shows more clearly the leap in complexity of the layouts of the recent past, which approaches the benchmark figure (54 lines) for the main street grid of modern Somers Town, see Table 7.

The second measure, which compares the grid or tree-like properties of layouts shows much more

Table 6

\begin{tabular}{|c|c|c|c|c|}
\hline Date band & Scheme no. & Axial lines & Dist:nondist & Maze index \\
\hline $\begin{array}{l}1890 \text { s benchmark } \\
\text { pre-1899 }\end{array}$ & $\begin{array}{l}\text { Somers Town street grid } \\
1\end{array}$ & $\begin{array}{l}94 \\
\text { n.a. }\end{array}$ & $\begin{array}{l}2.615: 1 \\
\text { n.a. }\end{array}$ & $\begin{array}{l}1.862 \\
\text { n.a. }\end{array}$ \\
\hline $1900-1924$ & $\begin{array}{l}2 \\
3 \\
4\end{array}$ & $\begin{array}{r}6 \\
5 \\
14\end{array}$ & $\begin{array}{l}1: 1 \\
0: 5 \\
0.750: 1\end{array}$ & $\begin{array}{l}2.5 \\
1.800 \\
2.071\end{array}$ \\
\hline $1925-1949$ & $\begin{array}{r}5 \\
6 \\
7 \\
8 \\
9 \\
10 \\
11\end{array}$ & $\begin{array}{r}22 \\
33 \\
32 \\
6 \\
12 \\
26 \\
5\end{array}$ & $\begin{array}{l}21: 1 \\
1.2: 1 \\
3: 1 \\
6: 0 \\
12: 0 \\
25: 1 \\
0: 5\end{array}$ & $\begin{array}{l}2.276 \\
2.303 \\
2.156 \\
1.500 \\
1.583 \\
2.346 \\
2.400\end{array}$ \\
\hline $1950-1969$ & $\begin{array}{l}12 \\
13 \\
14\end{array}$ & $\begin{array}{l}\text { n.a. } \\
11 \\
15\end{array}$ & $\begin{array}{l}\text { n.a. } \\
0.375: 1 \\
2.75: 1\end{array}$ & $\begin{array}{l}\text { n.a. } \\
2.545 \\
2.800\end{array}$ \\
\hline $1970-1989$ & $\begin{array}{l}15 \\
16 \\
17 \\
18 \\
19 \\
20\end{array}$ & $\begin{array}{l}21 \\
32 \\
\text { n.a. } \\
31 \\
78 \\
82\end{array}$ & $\begin{array}{l}21: 0 \\
3.571: 1 \\
\text { n.a. } \\
5.167: 1 \\
0.254: 1 \\
2.216: 1\end{array}$ & $\begin{array}{l}2.095 \\
2.062 \\
\text { n.a. } \\
3.710 \\
3.115 \\
3.183\end{array}$ \\
\hline post-1990 & $\begin{array}{l}21 \\
22\end{array}$ & $\begin{array}{l}\text { n.a. } \\
\text { n.a. }\end{array}$ & $\begin{array}{l}\text { n.a. } \\
\text { n.a. }\end{array}$ & $\begin{array}{l}\text { n.a. } \\
\text { n.a. }\end{array}$ \\
\hline 1990s benchmark & Somers Town street grid & 54 & $5: 1$ & 1.852 \\
\hline
\end{tabular}


Table 7

\begin{tabular}{llll}
\hline Late 19C to early 20C & 1920s-30s & Immediate post war & Recent past \\
\hline 8 & 19 & 13 & 49 \\
\hline
\end{tabular}

Table 8

\begin{tabular}{llll}
\hline Late 19C to early 20C & 1920s-30s & Immediate post war & Recent past \\
\hline 2.124 & 2.081 & 2.673 & 2.833 \\
\hline
\end{tabular}

variety through time. The benchmark ratios for the main street grid, of between three and five through streets for every cul-de-sac, are also characteristic of ten of the new estates. The mean for the sample is 6 through streets for every dead end. However, five estates are very griddy indeed and two are completely tree-like.

The 'maze index', the mean depth of the estate from its surrounding streets, is more independent of size. This was also the most stable figure for the local grid of Somers Town streets. All the estates are deeper internally than the street grid within which they sit. The average for the estate sample is 2.38 , as opposed to 1.852 in the $1890 \mathrm{~s}$ and 1.852 in the 1990s. However, the pre-war estates are more simple and clear to navigate than the postwar estates, which are strikingly more labyrinthine, see Table 8 .

The next representation, Figure 18, shows the convex break up of the open space of each estate, with all the spaces that have dwellings directly giving onto them highlighted in black and all the rest in a greyscale tone as before to show depth from building entrances. This time the tones show

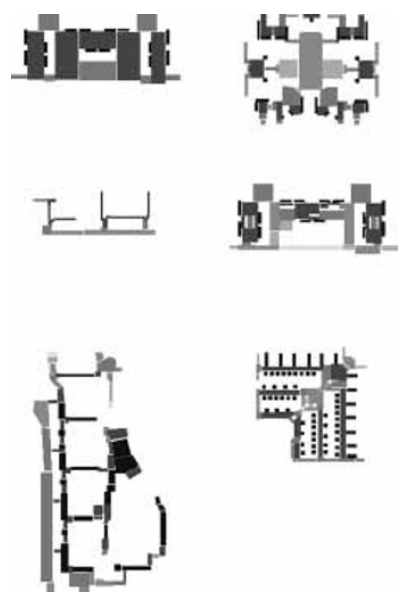

Figure 18 Convex break-up of the six estates. the depth each space is away from the nearest front door. This picture of convexity provides a more rigorous definition of enclosure in a way that also embraces the permeability from one local space to the next. It might be considered as more of an 'inhabitants dimension' of space, as it refers to the relations or lack of relations between people's dwellings and how these create a potential encounter field with people passing by the door. Table 9 gives the relevant convex measures for each estate.

As before, the sheer numbers of convex spaces on the estates should really be adjusted to take account of the size of each estate, a labour intensive task that is beyond the scope of an exploratory paper like this. However, we can set the convex break-up of the estates against the benchmark figures for the area in the 1890s and 1990s, during which period the convex articulation of the grid was quartered. It would seem that the convex complexity that was 'ironed-out' of the supergrid seems to have been sucked into the estates. The average convex break up for an estate is fifty spaces. The early and immediate post war estates are quite simple layouts: those from the inter war years and the recent past are more complex, especially those from the recent past, see Table 10.

If we take the size adjusted convex space to axial line ratio for the four time periods, we can unpack this a little more. The early and inter-war estates have a higher convex: axial ratio, a product of their strong organising global geometry that links courtyards together. The estates of the recent past have very high numbers of small convex spaces, but also a very high axial break-up. These estates are therefore experienced as particularly fragmented.

The 'no-neighbours score' measures the mean depth of all the convex spaces on the estate from 
Table 9

\begin{tabular}{|c|c|c|c|c|c|c|c|}
\hline Date band & No & Conv. & $\begin{array}{l}\text { No-neighbours } \\
\text { score }\end{array}$ & $\begin{array}{l}\text { Separation } \\
\text { index }\end{array}$ & $\begin{array}{l}\text { Constitutedness } \\
\text { rate }\end{array}$ & $\begin{array}{l}\text { Neighbourliness } \\
\text { score }\end{array}$ & $\begin{array}{l}\text { Decomposition } \\
\text { score }\end{array}$ \\
\hline 1890s benchmark & ST grid & 347 & 1.055 & 0 & $94.5 \%$ & 21.721 & 1 \\
\hline Pre-1899 & 1 & n.a. & n.a. & n.a. & n.a. & n.a. & n.a. \\
\hline $1900-1924$ & $\begin{array}{l}2 \\
3 \\
4\end{array}$ & $\begin{array}{l}14 \\
9 \\
26\end{array}$ & $\begin{array}{l}3.786 \\
1.556 \\
1.731\end{array}$ & $\begin{array}{l}5 \\
3 \\
4\end{array}$ & $\begin{array}{l}7.1 \% \\
44.4 \% \\
53.8 \%\end{array}$ & $\begin{array}{l}3 \\
2 \\
2\end{array}$ & $\begin{array}{l}\text { n.a. } \\
2.7 \\
1.615\end{array}$ \\
\hline 1925-1949 & $\begin{array}{r}5 \\
6 \\
7 \\
8 \\
9 \\
10 \\
11\end{array}$ & $\begin{array}{l}51 \\
63 \\
81 \\
22 \\
46 \\
27 \\
17\end{array}$ & $\begin{array}{l}3.157 \\
2.603 \\
2.432 \\
1.864 \\
2.935 \\
2.630 \\
3.059\end{array}$ & $\begin{array}{l}5.2 \\
3.8 \\
4 \\
4 \\
5.3 \\
3.2 \\
8\end{array}$ & $\begin{array}{l}21.6 \% \\
14.1 \% \\
28.4 \% \\
31.8 \% \\
13 \% \\
37 \% \\
17.6 \%\end{array}$ & $\begin{array}{l}6 \\
2 \\
2.5 \\
4 \\
2 \\
4 \\
2\end{array}$ & $\begin{array}{l}2.2 \\
2.2 \\
2.409 \\
2.5 \\
4 \\
1.4 \\
4\end{array}$ \\
\hline 1950-1969 & $\begin{array}{l}12 \\
13 \\
14\end{array}$ & $\begin{array}{l}\text { n.a. } \\
14 \\
20\end{array}$ & $\begin{array}{l}\text { n.a. } \\
3.071 \\
2.250\end{array}$ & $\begin{array}{l}\text { n.a. } \\
4 \\
4.3\end{array}$ & $\begin{array}{l}\text { n.a. } \\
57 \% \\
25 \%\end{array}$ & $\begin{array}{l}\text { n.a. } \\
1 \\
5\end{array}$ & $\begin{array}{l}\text { n.a. } \\
1.3 \\
1.154\end{array}$ \\
\hline 1970-1989 & $\begin{array}{l}15 \\
16 \\
17 \\
18 \\
19 \\
20 \\
21 \\
22\end{array}$ & $\begin{array}{l}48 \\
82 \\
\text { n.a. } \\
42 \\
103 \\
187 \\
\text { n.a. } \\
\text { n.a. }\end{array}$ & $\begin{array}{l}2.500 \\
2.293 \\
\text { n.a. } \\
3.357 \\
1.573 \\
2.802 \\
\text { n.a. } \\
\text { n.a. }\end{array}$ & $\begin{array}{l}5 \\
4 \\
\text { n.a. } \\
7.3 \\
4 \\
5.3 \\
\text { n.a. } \\
\text { n.a. }\end{array}$ & $\begin{array}{l}29.1 \% \\
30.5 \% \\
\text { n.a. } \\
16.7 \% \\
59.2 \% \\
21.4 \% \\
\text { n.a. } \\
\text { n.a. }\end{array}$ & $\begin{array}{l}2 \\
5 \\
\text { n.a. } \\
7.429 \\
1.5 \\
1 \\
\text { n.a. } \\
\text { n.a. }\end{array}$ & $\begin{array}{l}2.538 \\
2.250 \\
\text { n.a. } \\
3.667 \\
1.353 \\
3.077 \\
\text { n.a. } \\
\text { n.a. }\end{array}$ \\
\hline post 1990s benchmark & ST grid & 87 & 2.460 & 3.2 & $24.1 \%$ & 4.281 & 1.167 \\
\hline
\end{tabular}

Table 10

\begin{tabular}{lllll}
\hline & Late 19C to early 20C & 1920s-30s & Immediate post war & Recent past \\
\hline Number conv. & 16.3 & 43.9 & 17 & 92.4 \\
Conv:axial & $2: 1$ & $2.3: 1$ & $1.3: 1$ & $1.9: 1$ \\
\hline
\end{tabular}

Table 11

\begin{tabular}{llll}
\hline Late 19C to early 20C & 1920s-30s & Immediate post war & Recent past \\
\hline 2.358 & 2.669 & 2.661 & 2.505 \\
\hline
\end{tabular}

all the ground floor dwelling entrances. A street grid or 'all-neighbours' model scores 1 because all its segments are constituted by front doors. A perfect tree or 'no-neighbours' model scores 2.75 with two branches, 3.25 with four branches and 3.56 with eight branches. The benchmark figures for the supergrid of Somers Town were 1 in the $1890 \mathrm{~s}$ and 2.5 in the 1990s. The average for all the estates is a score of 2.548, a 'not quite' noneighbours model. The estates and the remaining constituted streets have an almost identical interface with the dwellings. The score is stable across all four time periods, see Table 11 .

The 'separation index' measures the average number of convex steps from the estate boundary with the local urban street grid to the nearest front door on the estate. The benchmark figures for the Somers Town supergrid with its surrounding streets was zero in the 1890s and 3.2 in the 1990s. The average for the estates with their surrounding streets is 4.7. Again, the estates of the recent past are more separated at the boundary than those of earlier periods, see Table 12.

The constitutedness rate, the percentage of all convex spaces that have front doors, has dropped in the street grid of Somers Town from $94.5 \%$ in the 1890 s to $24.1 \%$ in the 1990 s. From a situation in which it was difficulty to avoid 'being on the doorstep', a pedestrian now has just a one in four chance of walking by someone's front door. The 
Table 12

\begin{tabular}{llll}
\hline Late 19C to early 20C & 1920s-30s & Immediate post war & Recent past \\
\hline 4 & 4.8 & 4.2 & 5.1 \\
\hline
\end{tabular}

Table 13

\begin{tabular}{llll}
\hline Late 19C to early 20C & 1920s-30s & Immediate post war & Recent past \\
\hline $35.1 \%$ & $23.4 \%$ & $41 \%$ & $31.4 \%$ \\
\hline
\end{tabular}

Table 14

\begin{tabular}{llll}
\hline Late 19C to early 20C & 1920s-30s & Immediate post war & Recent past
\end{tabular}

Table 15

\begin{tabular}{llll}
\hline Late 19C to early 20C & 1920s-30s & Immediate post war & Recent past \\
\hline 2.16 & 2.67 & 1.22 & 2.58 \\
\hline
\end{tabular}

chance is a little better on an estate, as on average $29 \%$ of the estate spaces are constituted. Again, the figures vary by time band, see Table 13 .

Front doors occupy a greater proportion of the interface in relatively simple layouts of the early and immediate post war estates; they are least prominent on the estates of the 1920s and 30s, which have few entrances and large expanses of unconstituted estate space.

The drop in the 'neighbourliness score' from streets to estates is not surprising since it was the most striking feature of the interface maps of Somers Town. The benchmark figures for the 1890s and 1990s are 22 and 4, respectively. The average for the estates is 3.1 , with very little variation over time. Two schemes, both post-war, show a score of 1 , which means that each front door has its own convex space and no next-door neighbours at all, see Table 14 .

Finally, the 'interface decomposition score', which divides the number of convex spaces in the shortest path that can be taken to link all the dwellings in the estate together, by the number of constituted spaces - that is, it ignores the impact of all extra unconstituted convex spaces close to the estate entrances or around the back of the housing blocks - divides the estates into two groups, reflecting the relative simplicity of early and immediate post war layouts and the greater complexity of inter war and recent estates. The comparable value for streets is 1 or thereabouts. The average for all the estates is 2.27 , see Table 5 .

\section{The modernist urban genotype}

By now, it is stating the obvious to point out that the new morphologies are all small-scale, separate, inward-facing, unconstituted and hierarchical whereas the old were large-scale, integrated, outward-facing, constituted and direct. However, the measures have enabled us to quantify the extent of this change and to fill in the detail. The changes are summarised in Table 16. Taken together, the figures tell an interesting story.

Only one measure shows any degree of continuity between streets and estates, the distributed: nondistributed (through street; cul-de-sac) ratio, and even this disguises some radical experiments with grids and tree-like morphologies within the overall figures. All the remaining figures show evidence of a profound morphological change from streets to estate morphologies.

Some measurable morphological features of 
Table 16

\begin{tabular}{ll}
\hline Measure & \multicolumn{1}{c}{ Interpretation } \\
\hline Separation index & $\begin{array}{l}\text { Street segments are unconstituted by their adjacent surfaces and the shallower estate spaces, } \\
\text { close to the streets, are also unconstituted } \\
\text { Inside the estate, the axial structure of the layout is elaborate and labyrinthine, so that walking } \\
\text { through the interior of the estate takes more axial steps than going around the perimeter } \\
\text { But most of the internal estate space that has been created by the new layout is also quite deep from } \\
\text { any of the dwelling entrances, so that it is not immediately accessible to residents }\end{array}$ \\
No-neighbours score & $\begin{array}{l}\text { Which means that there are lots of blank-walled spaces } \\
\text { And the dwellings are fragmented and separated from one another as well as from the outside, } \\
\text { so that it is not possible to take any longer distance (i.e., several step) journeys without walking } \\
\text { through at least some blank-walled spaces }\end{array}$ \\
Decomposition score & $\begin{array}{l}\text { Very small numbers of dwellings share a common external space } \\
\text { All the longer axial lines tend to be unconstituted; conversely, the closer to the dwellings, } \\
\text { the shorter the axial line becomes }\end{array}$ \\
Neighbourliness score & All the larger convex spaces tend to be unconstituted, several steps deep from dwelling entrances \\
Axial length &
\end{tabular}

estates emerge at the outset and immediately stabilise. These include the shift from an 'allneighbours' to a 'no-neighbours' model to govern the depth of the estate layout, and a sharp reduction in the 'neighbourliness score' that measures the number of next-door neighbours with which each individual home shares a space. Compared to streets, estate layouts are designed to separate and reduce physical contact among close neighbours.

A second set of measures based on axiality, the maze index and the convex: axial ratio, pick up differences between pre and post war estates. Post war estates are more small-scale and articulated.

Other measures, such as the amount of convex break-up, the constitutedness rate and interface decomposition score, show a sharp overall drop from street based morphologies but highlight a difference between simple and complex estates. However you look at it, from the point of view of people's experience passing through or as a resident getting to know people in other parts of the estate, in the more elaborate estates the interface is attenuated and fragmented.

A final group of measures confirm that there was an initial break with street morphologies, but also there has been a leap in the internal complexity of the estates of the recent past. These include the mean number of axial lines on the estate, which rises sharply in the more recent examples, and the 'separation index', which first sharply ruptures the interface between dwellings and streets and then pulls the most accessible dwellings even deeper inside the estate's outer boundary.

\section{Ruptured interfaces}

Indeed, the whole story is one of a ruptured interface between dwelling and street. However, this has had two effects not one. The first has already characterised as being from an 'all neighbours' to a 'no neighbours' model. The second is that, from having 'strangers by the door', estate morphologies make inhabitants 'strangers to one another', because local residents can no longer identify people with where their homes are, whilst real strangers passing through have been eliminated from the interior of the estate altogether by means of its intimidating, bounded and labyrinthine layout.

When we originally formulated the new, now modernist, urban genotype, we had in mind a 'spiral' as the architectural 'parti' for the genotype. Rather like the morphology of a shell, we imagined a scenario in which axial and convex space gradually spiralled in upon itself on the journey from the mouth of the shell - the estate entrance - to its core - the front door. Of course, like most analogies, this turned out to be too simple and idealised a form, and as is so often the case, real life turns out to be much more disorderly and messy.

At the same time, the ideas seem to have been realised in three distinct stages, which do relate configurational features of the estates to their 
architectural composition and to the size of their constituent spaces. In the first phase, most estates seem to have taken a set-back or courtyard form that followed the model set by philanthropic housing and which can be recognised by its simple open space map. This was followed by a more complex geometrical phase in the inter-war years, that can be recognised by its distinctive 'ink-blot' open space maps, and finally by a more organic and irregular, contorted, labyrinthine phase in which the open space maps look like an overgrown village morphology. The last two phases were separated by a brief return, perhaps motivated by post-war austerity, to the simple morphologies of the past.

At level of urban 'structure' there has been a progressive tearing apart of the interface which has accelerated in the recent past; meanwhile, the compositional or 'order' principles have shifted from an overall simple geometry in phase one, to the use of motifs stamped-out onto the site in phase two and then in phase three, to a nested hierarchy of smaller and larger enclosures. Whilst there is not a simple, direct progression from longer, shallower axial lines at the periphery to shorter ones in the heart of the estate, nor from larger unconstituted convex spaces to smaller constituted spaces, the greyscale mixing does show a faint echo of this spiral effect.

Returning to the 'hypothetical cases' in Figure 5 which were used to illustrate the measures earlier on in the account, it can now be seen that these cases illustrate in principle, the three main configurational stages in the evolution of the real housing morphologies. They turn out to be paradigm cases, first for streets and then for the three main phases in the evolution of estate morphologies.

\section{Creating urban life}

Common sense suggests that the urban transformation which has just been described in some detail, that took place in just every town and city in the UK (and indeed which has occurred to a greater or lesser extent in most parts of the modern, urbanised world during the course of the twentieth century), was not just a change in the physical, spatial ordering of the residential built environment but that it must also have had some consequences for the way in which people deployed themselves in space, encountered one another and behaved towards one another. This was already implied in the contrasting terms we invented to try to capture the essential spatial property of the two urban surfaces before and after transformation; the 'all-neighbours' model and the 'no-neighbours' model, respectively, as these also speak of a transformation in the preconditions for sociability.

The 'theory' of how this space-society relationship might be constructed - that is, by means of 'spatial and transpatial' groupings and 'correspondence and non-correspondence' modes of relating space to society - were also set out in 1979 in a paper called the 'Architecture of Community', though this was not published until 1987 (as part of a special issue of Architecture and Behaviour devoted to space syntax: Hanson and Hiller, 1987, pp. 249-271). In practice, however, what seemed clear was that the modernist urban genotype with its 'ruptured interface' between street and dwelling and its 'no-neighbours' model for relating dwellings to one another, had the effect of tearing apart and remaking the everyday fabric of ordinary people's lives, in that many routines, habits and practices that were once commonplace are now a part of history, at least so far as the residents of Somers Town are concerned. Nevertheless, they are part of living history, a history which was captured by empirical sociologists after World War II and which still features in older people's reminiscences today. This is just the barest outline of the consequences of the spatial transformation for behaviour and for sociability, see Table 17.

\section{The 'social structures' of space}

In inner city areas like Somers Town, the consequences of the modernist urban genotype seem to have adversely affected everyone's lives to some extent and some people have been affected more than others. Yet at the same time, in other parts of London, middle class 'frontiersmen' were beginning to seek out and buy into the old way of life in the few remaining traditional urban neighbourhoods that had so far escaped the bulldozer. Elsewhere, sociologists were able to point out that not everyone found the new morphologies so alienating. Indeed, the fact that some of the most wealthy and socially-advantaged people of all chose to live (self-segregate) in 


\begin{tabular}{|c|c|c|c|}
\hline & \multirow[t]{2}{*}{ Impact of transformation } & \multicolumn{2}{|c|}{ How behaviour was affected } \\
\hline & & From & To \\
\hline 1 & Relation between building interiors and the street & A doorstep culture & Strangers frozen out \\
\hline 2 & The route potential of the system & Bumping into people & Hanging about \\
\hline 3 & Domestic living arrangements & $\begin{array}{l}\text { Dropping in or popping round, } \\
\text { mutual help }\end{array}$ & Having people round, entertaining \\
\hline 4 & The number and scope of people's acquaintances & Scores of acquaintances & A handful of close friends \\
\hline 5 & The information field of public space & Reputations society & Opinion formed by the media \\
\hline 6 & Access to and choice of local facilities & Corner shop family firm & Supermarket chain store \\
\hline 7 & The informality or formality of social arrangements & Casual, informal & Pre-arranged, formal \\
\hline 8 & Children's play & $\begin{array}{l}\text { At the doorstep, on the street, } \\
\text { supervised }\end{array}$ & At home, on the estate, unsupervised \\
\hline 9 & The social life of elders & Embedded & Isolated \\
\hline
\end{tabular}

high rise blocks seemed to provide a cast-iron alibi for architecture, which showed that morphology has nothing at all to contribute to the sum of human happiness nor can it be held responsible for people's feelings of social isolation or exclusion.

An alternative approach would be to try to account for people's divergent experiences by showing how space fits into people's lives in different ways, so that two apparently contradictory reactions to the same housing morphology can be shown to be equally valid, depending on people's circumstances. Left to their own devices, different class fractions and sub-cultures within a society maintain their identity and carry on their everyday way of life without much conscious thought. Each of their lifestyles appears natural, but each is undoubtedly different. Each is based on a complex and different mix of spatial and transpatial groupings realised in correspondence or non-correspondence with space. We have referred to the organising principles that underpin these encounters and interactions as social 'solidarities', and it would seem that all societies are made of at least two (and often many more) sub-groups that form 'differential solidarities' (such as those between the genders, people of different wealth or status, or people of different social class).

Differential solidarities seem to be a very general property of societies. It is also a property that is of fundamental importance for the understanding of space, since space is likely to be ordered in the image of a relation between solidarities, whether this is a relation of inequality or equality. This is no less true of contemporary societies, and other class societies, than it is of simpler societies, where the relation between male and female solidarities is perhaps the dominant force shaping space (SLS, p. 240)

At the time of which we are speaking, different middle class and working class fractions were no exception, in that they employed different solidarity principles that were 'encoded' into different daily routines and practices and that led to different modes of spatial co-presence and virtual community. These 'code' differences were realised in patterns of local encounter and in different ways of organising the family home.

In the 1970s there seemed to be four of these subgroups, each with a different orientation toward economic and social life, that were caught up in the process of urban transformation:

- the 'traditional working classes', made up of people in the industrial trades, the manual, factory and shopfloor workers who used to be referred to as the 'respectable poor' and who had appropriated the street as a key 'lifespace' for all the reasons that have already been set out;

- the 'new working classes', blue-collar workers and people in the emerging service industries who were aspiring to 'improve' their position in life by distancing themselves from the easy informality of the street and by adopting a more up-market way of life;

- the 'traditional middle classes', bankers, lawyers, accountants and the like, people in the established professions who preferred a more homecentred, formal and suburban lifestyle that had 
Table 18

\begin{tabular}{|c|c|c|}
\hline & Low status & High status \\
\hline $\begin{array}{l}\text { Production } \\
\text { Social reproduction }\end{array}$ & $\begin{array}{l}\text { Conformers (TWC) } \\
\text { Aspirers (NWC) }\end{array}$ & $\begin{array}{l}\text { Transformers (NMC) } \\
\text { Achievers (TMC) }\end{array}$ \\
\hline
\end{tabular}

grown up alongside but which was in many ways the antithesis of a street-based culture; and

- the 'new middle classes', media people whose work was to create and give substance to new ideas, images and objects that would help fuel international competitiveness, economic growth and social change. Today it is perhaps more illuminating to characterise these groups by their social orientation, as conformers, aspirers, transformers and achievers, than by their social class, see Table 18.

Because of their differences in orientation and their preferred forms of solidarity, the four groups experienced and interpreted both the old and the new morphologies in quite different ways. They did not form identical experiences of the old and new morphologies because these did not fit into their preferred modes of interaction and socialisation in precisely the same way. There is no mystery about why some people like living in flats but others prefer streets, Table 19.

What is worrying, though, is that the new morphologies were aimed at precisely those people who were least equipped, socially, to cope with the lifestyle changes that were demanded by a shift from an 'all neighbours' to a 'no neighbours' spatial model. Not only that, an achiever or an aspirer who was 'out of place', that is, living hugger-mugger on an urban street, had the option to disengage because decisions to participate (or not) lay with the householder. A conformer who was 'out of place' living on a housing estate had no such choice because the decision to minimise social contact was built into the spatial layout itself.

Clearly urban society has moved on and, even if we wanted to, we cannot as members of the 'information age', simply return unreflexively to the street-based culture of the recent past. In any case, the argument is not that street-oriented, outward-facing and stranger-friendly housing layouts can in any sense compensate for economic and social inequalities, but that they are more empowering than the space of the 'hard solution'. In today's politicised language we might speak of giving local residents choice and control over their own lives, maintaining people's independence and dignity or of providing less discriminatory, more architecturally enabling environment. That language was not available twenty years ago, but it was clear even then that the practical consequence of the shift from streets to estates was to remove the control over the interface between private and public life from local residents and to assign that function, through design, to the space itself. What is more, the disabling effects of the urban transformation had the greatest impact on the weakest and least powerful people socially; those who depended on their local environment the most to

Table 19

\begin{tabular}{|c|c|c|}
\hline Lifestyle orientation & Traditional morphology & Transformed morphology \\
\hline Conformers & $\begin{array}{l}\text { Probabilistic street-orientated } \\
\text { local solidarity based on dense, } \\
\text { strong spatial networks }\end{array}$ & $\begin{array}{l}\text { Does not adopt a new lifestyle but } \\
\text { cannot make the old one work in the } \\
\text { new morphology as contact is frozen out, } \\
\text { becomes more isolated }\end{array}$ \\
\hline Aspirers & $\begin{array}{l}\text { Uses distancing and avoidance to control } \\
\text { unwanted interactions, perceived as stand-offish }\end{array}$ & $\begin{array}{l}\text { Adopts a more home-centred } \\
\text { lifestyle plus formal visiting, } \\
\text { may join in formal associations } \\
\text { based on interest groups }\end{array}$ \\
\hline Achievers & $\begin{array}{l}\text { Does not normally chose to live here, } \\
\text { unless in a mansion flat in one of the } \\
\text { 'great' West End estates, } \\
\text { but might have a small 'pied a terre' } \\
\text { in town and a large country house }\end{array}$ & $\begin{array}{l}\text { Would not normally live in here } \\
\text { but in a suburb, lifestyle is based on } \\
\text { local conformity to accepted standards, } \\
\text { reinforced by formal house-to-house visiting } \\
\text { and joining clubs }\end{array}$ \\
\hline Transformers & $\begin{array}{l}\text { Uses the potential of both local space and 'transpace', } \\
\text { space acts as an 'insurance policy' } \\
\text { or as a 'mixing mechanism' to widen social contacts }\end{array}$ & $\begin{array}{l}\text { Socially more risky, but can survive just on } \\
\text { a very extensive and dense transpatial network, } \\
\text { may prefer the transformed space for its } \\
\text { insulating properties locally }\end{array}$ \\
\hline
\end{tabular}


Table 20

\begin{tabular}{lcll}
\hline Ideology & Popularised & \multicolumn{1}{c}{ Rationale } & \multicolumn{1}{c}{ Exemplar } \\
\hline High capitalist space & 1840s to 1920s & $\begin{array}{l}\text { Medical model, 'demoralisation' } \\
\text { and 'urban degeneration' }\end{array}$ & Prison, how to design a cell that will rehabilitate \\
Gendered space & 1890s to 1970s & $\begin{array}{l}\text { Functionality, the neighbourhood unit } \\
\text { Ethnic enclaves }\end{array}$ & Home, how to domesticate the street \\
\hline
\end{tabular}

support them in their everyday life, like children, elders, the sick and disabled, the unemployed.

\section{Paradigms for design}

We suggested in the Social Logic of Space, that the underlying social logic of the shift from street to estate morphologies within the modern, industrial urban societies might lie in a power inequality between competing social solidarities, and we can see here how streets and estates might it into different peoples lives in different ways. But it has also been shown here, analytically and quantitatively, that the transformation in the UK was cumulative and had three main phases, with measurably different spatial properties, and this evolution in design thinking also requires some explanation.

What seems to have happened is that the three phases were identified with three powerful sets of design ideas; ideas which both helped to justify the continued use of estate morphologies as a solution to social housing for each succeeding generation and also which fine-tuned the morphology within each major construction cycle. Architects and planners and, indeed, academics and researchers do not work in a vacuum. We are all products of our time, and we are guided in our design thinking by ways of seeing and describing the process which arise out of a more general social climate. In the case of social housing, architecture was informed by political and social concerns and by apparently 'scientific' ideas which made the new forms of housing seem natural and right, see Table 20.

Two prominent social accounts have traced the urban transformation back to the dominance of powerful ideologies that have served to obscure the relation between society and its spatial manifestations, one of which depends on a social class analysis of high capitalist space, the other on a feminist critique of patriarchal space. The first of these, a nineteenth century debate, can be traced back to the ideas that originated with the design of the first institutional buildings. The second can be traced back to the idea of the 'neighbourhood unit' that emerged in the USA during the 1920s in the proposals of Perry, Stein, Radburn and others to shape the new residential districts of the rapidly-expanding American gridiron cities.

The case for the first of these, high capitalist space, is briefly as follows. When the first modern housing estates replaced the rookeries in the late nineteenth century, they imported many of the spatial features of the then-new reforming institutions which had been given the brief of resolving the perceived 'problem' or 'threat' to the social order of people who appeared to be socially deviant - the prison, mental asylum and hospital - into housing design, see Table 21.

Table 21

\begin{tabular}{|c|c|c|}
\hline & Property & Characteristics \\
\hline 1 & $\begin{array}{l}\text { Inward-facing } \\
\text { morphology }\end{array}$ & Buildings orientated to courtyards in blocks surrounded by a clear outer boundary \\
\hline 2 & Free-standing blocks & Geometric building blocks in a 'parkland' setting, linked together by a clear system of paths \\
\hline 3 & Cellular planning & Internally a cellular system of separate rooms linked together by corridors \\
\hline 4 & Separation & $\begin{array}{l}\text { Classification and segregation of different types of inmates to correspond to the spatial sub-divisions, } \\
\text { so as to minimise cross-contamination }\end{array}$ \\
\hline 5 & Silence & $\begin{array}{l}\text { Controls over inmates' routines and habits to retrain their spatial demeanour and their behaviour } \\
\text { towards one another }\end{array}$ \\
\hline 6 & Surveillance & As a mode of control to ensure compliance \\
\hline
\end{tabular}


Table 22

\begin{tabular}{lll}
\hline \multicolumn{1}{c}{ Property } & Characteristics \\
\hline $1 \quad$ Open space barrier & $\begin{array}{l}\text { Buildings no longer back directly onto the streets but sit within an outer, landscaped, green belt } \\
\text { or 'cordon sanitaire' } \\
\text { The facades on the street side are highly articulated to break down the overall layout and enclose } \\
\text { (unconstituted) landscaped spaces around the perimeter }\end{array}$ \\
3 Set back facade & $\begin{array}{l}\text { The buildings are related together into a strong, governing architectural composition, } \\
\text { with a clear axis of symmetry that relates the community facilities together } \\
\text { The remainder of the open space is broken up into several large landscaped convex courtyards } \\
\text { that draw together a 'community of the eye', and which are separated from one another internally by } \\
\text { passage ways through the buildings or by small, chicained spaces }\end{array}$ \\
\hline
\end{tabular}

Table 23

\begin{tabular}{|c|c|c|}
\hline & Property & Characteristics \\
\hline 1 & Domains & $\begin{array}{l}\text { Estate space is designed as a nested hierarchy of spatial domains of increasing physical size, that } \\
\text { correspond to the various social groupings which link individuals and families into the entire community }\end{array}$ \\
\hline 2 & Semi-private space & $\begin{array}{l}\text { Each dwelling should have at least one and preferably several small 'buffer' spaces between the } \\
\text { front door and the public realm to protect the family private domain }\end{array}$ \\
\hline 3 & Clusters & Houses should be grouped together in small enclaves of close neighbours \\
\hline 4 & Semi-public space & Close neighbours should share an outdoor space that expresses their group identity \\
\hline 5 & Path hierarchy & $\begin{array}{l}\text { Routes should safeguard the territorial integrity of the hierarchy of spatial domains and their } \\
\text { constituent social groupings }\end{array}$ \\
\hline 6 & Public space & $\begin{array}{l}\text { Each level in the social hierarchy should be reflected in a public space that is a suitable size for its } \\
\text { social constituency, up to the level of the entire community }\end{array}$ \\
\hline 7 & Homogeneity & $\begin{array}{l}\text { Estates should be designed for interest groups of like-minded people, or for people of the same ethnic or } \\
\text { cultural background, and the design of space should be tailored to their precise needs, } \\
\text { aspirations and values }\end{array}$ \\
\hline
\end{tabular}

Through these shared concepts and ideas, first generation estates can trace their intellectual and spatial pedigree back to the design of the prison cell.

The second set of design ideas can be traced back to 1920s 'neighbourhood unit planning', which feminists have long-argued recasts space in the image of a gendered urban landscape in which the world of women (home, private, housewife) is split apart from and opposed to the world of men (work, public, breadwinner). Down-wind of the neighbourhood unit philosophy, a second generation of hard solution urban housing estates added a new layer of spatial complexity to the first generation of estates, see Table 22.

But there is also a third, more recent and highlyinfluential ideological prop that has allowed the urban transformation a third lease of life. The roots of these design ideas lie in the science of 'ethology', the study of social behaviour in animals in the 1940s, when Henri Hediger set out to replace cages with animal houses, like his paradigmatic Africa house, the plan of which is reproduced in Figure 19. They re-emerged in the human sciences in the 1960s and 70s, under the umbrella of 'proxemics', the study of human spacing. Once they had arrived, they quickly spawned design concepts such as 'territoriality', the 'ethnic enclave', 'community and privacy', the 'mosaic of sub-cultures' and 'defensible space'. The impact which these ideas have had on design is so recent as to be familiar, see Table 23 .

This time, the sources for the intellectual 'borrowing' and assimilation to architectural theory, Robert Sommer and especially Edward T. Hall, reveal that under the guise of socio-biology, what was being proposed was a theory of self-segregation and ethnic space. Hall's interest in proxemics

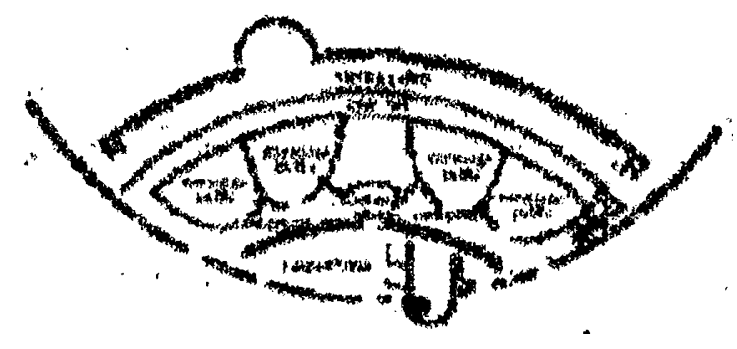

Figure 19 Africa House. 
was generated by what he saw as a major social problem for the USA, the impact of rural migration upon the American city; for, 'the implosion of the world population into cities is creating a series of destructive behavioural sinks more lethal than the hydrogen bomb'. (Hall, 1966, p. 155)

Different ethnic groups with their different, culturally-specific spacing mechanisms will, he argued, find migration to the American city difficult to adjust to and will inevitably experience city life as crowded and stressful. Stress is exacerbated where people of different ethnic backgrounds are crowded together, as this will invariably activate territorial behaviours and lead to heightened aggression. Wealthy people are able to avoid this threat altogether by choosing to inhabit separate residential neighbourhoods within the city, a form of 'self-segregation'. However, state housing programmes seldom allow for this and so the poor are crowded together 'in dangerously high concentrations'.

In order to resolve the problem of overcrowding, Hall proposed the idea of the 'ethnic enclave'; that is, 'a definite, well-delineated amount of contained space...that will hold an entire community' (p.167). An ethnic enclave is a group territory, the function of which is, over a very long period of time, to convert rural migrants into city dwellers and at the same time to strengthen social controls and combat lawlessness. Thus, enclaves 'act as a lifetime reception areas in which the second generation can learn to make the transition to city life' (p. 157). Even so, where there are too many migrants moving in, not enough people moving on and no room to expand, the result is overcrowding and so the enclave (territory) exhibits pathological symptoms; it becomes a 'sink' that is dangerously out of control and beyond the reach of law and order. Like the English philanthropists of a century before, Hall ignores or discounts poverty and lack of opportunity as a contributory factor to social inequality in the American cities, but his diagnosis is founded on ethnicity rather than on class differences.

Having diagnosed the problem in this way, the solution suggests itself.

In animal populations, the solution is simple enough and frighteningly like what we see in our urban renewal programmes and well as our suburban sprawl. To increase density in a rat population and maintain healthy specimens, put them in boxes so they can't see each other, clean their cages and give them enough to eat. You can pile the boxes up as many stories as you wish. Unfortunately, caged animals become stupid, which is a heavy price to pay for a super filing system... (p. 157)

The 'humane' alternative, one which has already been clearly demonstrated in Hediger's work with captive animals, is to introduce design features that will counteract the ill effects of the sink but not destroy the enclave in the process' ( $p$. 157). Thus the solution to ethnic tensions is perceived to be to segregate people of different origins and to design a better, more congenial hierarchy of spaces from public to private that will enable each social species to live healthily at an abnormally high density, until such time as they or more accurately, their descendants, have adjusted to the denser urban spacing.

A final, disturbing twist to this set of ideas is it is not predicated on an understanding of natural habitats but in attempts to design artificial zoo environments for captive wild animals, which were only later expropriated to the design of ethnic enclaves for different human species. The unpalatable origin of this analogy is therefore rooted in the problem of how to design a better cage.

The design moves that were inherent in each of the three phases of the urban transformation of Somers Town are precisely those which we see echoed in these wider social debates. Most architects prefer not to think about how their design ideas have come into being, but in the case of social housing there would seem to be a duty to do so, for it is quite possible that our thinking has been polluted along the way by attitudes and values that discriminate against people on the grounds of social class, gender and ethnic identity. As these are the three basic 'facts' of the human condition upon which people's social identities are constructed, it is important to understand the role that ideology has had in the evolving public debate about space and society, and in perpetuating social inequalities whilst appearing to resolve them.

\section{Mixed space-use and L-shaped distributions}

Meanwhile, the programme of empirical research 
that began in 1980 in the paradigm 'street' and 'estate' layouts of Barnsbury and Marquess Road, set out directly to observe the effect that the spatial layout of an urban area had on its everyday pattern of use and movement. We thought at first that we should be looking for and recording encounters between people, but it did not take us long to realise that the fundamental relation between urban space and society was not encounter, but 'co-presence'. This is important, because co-presence (or its absence) is a 'generic' feature of societies. It is a precondition for face-to-face human social interaction without in any way determining what takes place. Part of the social function of towns and cities is to structure co-presence among people of different ages and genders, between inhabitants and strangers or outsiders, among people of different occupations or social classes, and within economic, civic and religious life.

We have now assembled the body of empirical evidence that relates to differential patterns of copresence and encounter among people in the urban public realm, among inhabitants and strangers, adults and children, the genders and by younger and older people. 'Mixed co-presence' or 'mixed space use' is, it seems is as important to what we in the UK have come to recognise as 'urban vitality' as the principle of 'mixed (that is, not zoned) use'. As studies are accumulating from all over the world, we are gradually coming to recognise that cities in different parts of the world are spatially configured in different ways, so that it is no longer acceptable to speak of the 'gridiron' city, the 'organic' city, the 'European' city or the 'Islamic' city, as if they were all alike. It follows, that if the social function of cities is to structure fields of co-presence, these differences in configuration should allow us to decode social information and build more powerful social theory.

We have also begun to identify some of the social structures of space that give rise to social pathology, such as the 'L-shaped problem', a characteristic L-shaped distribution in the scattergram correlating observed space use by different groups, such as adults and children, which shows that the spaces that are prioritised by one group are avoided by the other. L-shaped distributions and mixed space-use may well be the long term, emergent social effects of designing housing layouts in such a way as to achieve either a correspondence or non-correspondence between space and social groupings. They are the missing link between ideological intentions and lived experiences.

We can now show that the transformation from street based housing areas to housing estates has produced observable, quantifiable perturbations in the field of co-presence that we call the virtual community that affect not just the absolute numbers of people that are about but also the way in which people of different ages, ethnicities, genders and social classes either blend together or fail to encounter one another. It is who is out-andabout on the streets, where they go to and which places they avoid that makes a particular place 'feel' friendly, uncongenial or threatening to different people. These long term effects are perhaps the key to what makes for a successful, working local community of the kind that most people want to belong to or what leads to an area's long term social decline.

\section{Postmodern space}

However, if we now return to our principal prosecution witness for the social effects of the urban transformation, space itself, this tells us that even as we were in a position to show that the adverse effects of the modernist urban transformation were an aspect of reality not just of people's imaginations, fashions in architecture and urban design were beginning to change. A second urban transformation is now under way which, in time, could well consign the 'modernist urban genotype' to history by reversing many of its characteristics and returning to the street-based, outward-facing morphologies that preceded it.

The builders are once more active in Somers Town. Estate 21, the first model housing by the St Pancras Housing Association, has been one of the first housing estates in the area to invert its morphology and re-address the street. Despite the sheer physical difficulties of adapting existing layouts to take account of the changed design climate, others are now following suit, and several estates in our sample now have at least a few homes at ground level that open onto the surrounding streets. New housing in the area, like Estate 22, has all been built with a front door onto the street.

However, the paradigm for the latest urban 


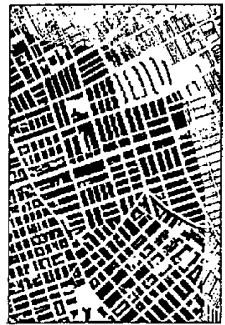

Figure 20 19th century Hulme.

transformation is not in London but in Hulme, Manchester, an inner city neighbourhood of roughly the same area as Somers Town just ten minutes walk away from the city centre. Here, what was once Britain's largest system-built housing estate, the Crescents, see Figures 20-22, has just been demolished and is being rebuilt as a mixed-use neighbourhood that claims to derive its morphology from the traditional streets of terraced houses that were demolished in their turn in the 1960s, to make way for the distinctive eight storey high concrete slabs.

Hulme's design guide, developed in partnership with local residents to guide the implementation of any future plans for the neighbourhood (there is no masterplan) is a model expression of the virtues of permeability, integration and constitutedness. If we recall the principles of the 'great estates', the wheel seems to have come round full circle and the residents of Hulme are apparently seeking to tap into a much older tradition of urbanity - one in which to be 'urbane' meant to be 'civilised, courteous, elegant and refined' and a tradition which some say we in the UK lost touch with over a century ago.

However, in the case of Hulme, this may turn out to be an unrealistic objective. Seven years into the regeneration project, large areas of Hulme are derelict and several more schemes are still a building site, so we cannot assess the full impact of the latest thinking. However, we can detect

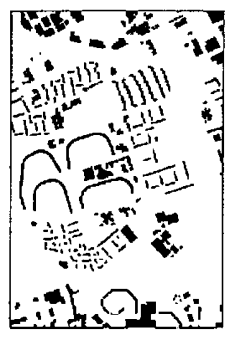

Figure 21 Hulme, The Crescents.

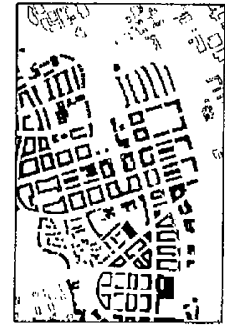

Figure 22 Hulme, Regeneration Plan.

some straws in the wind from what has been proposed and from what has been built already. This account will draw attention to just three; one at the overall level of Hulme's layout, the second in the detailed design of some of its model terraced housing and the third in the design of its 'flagship' mixed-use urban block.

So far as the overall shape of Hulme is concerned, the open space maps from the 1890s and the 1990s show that whilst the old Stretford Road, the symbol of Hulme's historic connections to the city centre, has been rebuilt as a local, shallow 'high street' that reaches out across the Mancunian Way to the old city centre, most of the area is still cut off from its surroundings, see Figures 23 and 24. The best sites, shallow to and accessible from the supergrid of 'urban motorways' have already been annexed by industry, retail and big business. For the most part, the housing has been relegated to the backwaters of Hulme.

Old and modern Hulme have almost identical numbers of axial lines but, whereas old Hulme was very griddy indeed, with a distributed: nondistributed ratio of 19:1, new Hulme has more dead end spaces, 2.4:1. Because it was so griddy and interconnected locally, Old Hulme's 'maze index' was lower than Somers Town's in the 1890s, at 1.536; today, new Hulme's maze index is higher at 2.688. This figure is also higher than the mean value for Somers Town's estates and comparable with the more labyrinthine, post war estates, see Table 24.

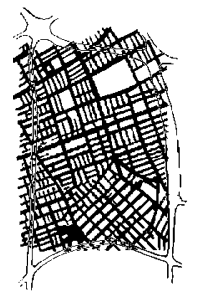

Figure 23 19th century Hulme. 


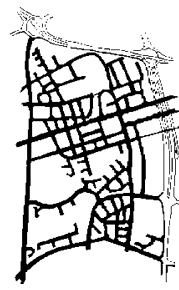

Figure 24 20th century Hulme.

At the other extreme, when we look in detail at the form of Hulme's new 'traditional' terraced housing, admittedly the morphologies are, for the most part, outward-facing and most residential streets are constituted by dwellings, but in the heart of some of the new urban blocks we can see relics of the internal complexity that bedevilled the estates of the recent past, see Figure 25.

Finally, when we examine in detail a prototypical mixed-use urban block, Homes for Change, designed by and for a co-operative of local housing activists, we do not see the syntactic principle of 'marginal separation by linear integration' at work but a rather more simple principle that non-residential uses face outwards to constitute the street but housing faces inwards and clusters around a central, gated courtyard.

\section{Re-inventing community}

Yet whatever the shortcomings, the ideas which are driving the transformation of Hulme forward are led by moves to rediscover, or perhaps more accurately to reinvent, the city as an urban way of life for ordinary people. This reinvention of an urban way of life based on face-to-face community does not seem just to be born out of an unreflexive nostalgia for the past, but to be firmly rooted in the needs of contemporary urban society. Just as the previous design paradigms that produced the modernist urban genotype seem to have been driven by the need to bring large numbers of workers together in the interests of industrial production, so now it is tempting to

Table 24

\begin{tabular}{lrll}
\hline Date band & Axial lines & Dist:nondist & Maze index \\
\hline 1890s Hulme & 110 & $19: 1$ & 1.536 \\
1890s SomersT & 94 & $2.615: 1$ & 1.862 \\
1990s Hulme & 109 & $2.406: 1$ & 2.688 \\
1990s SomersT & 54 & $5: 1$ & 1.852 \\
\hline
\end{tabular}

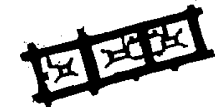

Figure 25 Open-space map of typical urban blocks in Hulme.

speculate that 'rethinking urbanism' to 'stitch the city together again' in places like Hulme's reconstituted Stretford Road is, perhaps, an unlikely by-product of the 'information society'.

If the problem of the nineteenth century industrial city was urban concentration and the solution segregation, then it is becoming increasingly clear that the issue which is uppermost in minds of today's social commentators is the apparent loss of face-to-face connections between people, as a result of the decay of the old industrial base, the rise of consumerism and the impact of modern telecommunications, including the internet and the 'virtual' world. Concern is mounting in the UK and the USA among city-watchers about the 'death of public space'. It may be that our increasingly fragmented and fissiparous existence requires that society itself needs once more to be embodied and spatialised. Now that the social problem is atomisation, the social logic of space predicts that we concentrate.

\section{References}

Hall, E.T. (1966) The Hidden Dimension. Bodley Head, London.

Hanson, J. and Hillier, B. (1987) The Architecture of Community, special issue of Architecture and Behaviour devoted to space syntax, 3(3), 249-271

Hanson, J. (1989) Order and structure in urban design: the plans for the rebuilding of London after the Great Fire of 1666, Ekistics, January-April, 56(334/ 5), 22-42

Hillier, B. and Hanson, J. (1984) The Social Logic of Space. Cambridge University Press, Cambridge.

Hillier, B. (1996) Space is the Machine. Cambridge University Press, Cambridge.

Ian Haywood Partnership, (1997) Somers Town Community Safety Project, mimeo

Morrison, A. (1896) A Child of the Jago. Methuen, London.

Smith Morris, E. (1997) British Town Planning and Urban Design: principles and policies. Longman, Harlow.

Sommer, R. (1969) Personal Space: the behavioural basis of design. Prentice Hall, New Jersey.

Summerson, J. (1962) Georgian London. Barrie and Jenkins, London.

Tarn, J. (1969) Working Class Housing in 19th Century Britain, Architectural Association Papers, No. 7, Lund Humphries, London 